\title{
Bone histology reveals the first record of titanosaur (Dinosauria: Sauropoda) from the Late Cretaceous of Bulgaria
}

\author{
Vladimir Nikolov, Marlena Yaneva, Docho Dochev, Ralitsa Konyovska, \\ Ivanina Sergeeva, and Latinka Hristova
}

\begin{abstract}
The fossil record of Mesozoic tetrapods in Bulgaria is sparse and currently limited to the Maastrichtian limestones of the Kajlâka Formation. Herein we report on two bone fragments from the Upper Cretaceous, lower Santonian to/or lower Campanian, coal-bearing sedimentary succession of the Western Srednogorie, Western Bulgaria. Due to being very fragmentary in nature, it is not possible to assess their taxonomy based solely on osteological characters and a paleohistological analysis is used as an alternative method for taxonomic identification. Our analysis reveals an informative combination of histological characteristics, most notably: absence of free medullar cavity, thick cortex affected by extreme Haversian remodeling with up to five generations of secondary osteons, and laminar bone in the mid-cortex characterized by moderately to highly organized bone matrix. These results do allow us to tentatively assign the studied fossils to a titanosaurian sauropod. The interpretation of the new Bulgarian material as belonging to Titanosauria is intriguing, because it comes from a time interval when sauropods are rare or completely absent in the fossil record of Europe. The histologically assessed ontogenetic stage for one of the fragments suggests that it may come from a sexually mature animal.
\end{abstract}

Vladimir Nikolov. National Museum of Natural History, Bulgarian Academy of Sciences, 1 Tsar Osvoboditel Blvd., 1000 Sofia, Bulgaria. vlado_raptor@mail.bg

Marlena Yaneva. Geological Institute "Strashimir Dimitrov", Bulgarian Academy of Sciences, Department of Earthquake Geology, Academic Georgi Bonchev Str., bl. 24, 1113 Sofia, Bulgaria.

marlena@geology.bas.bg

Docho Dochev. Sofia University “St. Kliment Ohridski”, Department of Geology, Paleontology and Fossil

Fuels, 15 Tsar Osvoboditel Blvd., 1504 Sofia, Bulgaria. dochev@gea.uni-sofia.bg

Ralitsa Konyovska. National Museum of Natural History, Bulgarian Academy of Sciences, Department of Palaeontology and Mineralogy, 1 Tsar Osvoboditel Blvd., 1000 Sofia, Bulgaria. rkonyovska@nmnhs.com

Nikolov, Vladimir, Yaneva, Marlena, Dochev, Docho, Konyovska, Ralitsa, Sergeeva, Ivanina, and Hristova, Latinka. 2020. Bone histology reveals the first record of titanosaur (Dinosauria: Sauropoda) from the Late Cretaceous of Bulgaria. Palaeontologia Electronica, 23(1):a10. https://doi.org/10.26879/879

palaeo-electronica.org/content/2020/2940-bulgarian-titanosaur

Copyright: March 2020 Society of Vertebrate Paleontology.

This is an open access article distributed under the terms of the Creative Commons Attribution License, which permits unrestricted use, distribution, and reproduction in any medium, provided the original author and source are credited. creativecommons.org/licenses/by/4.0 
Ivanina Sergeeva. Geological Institute "Strashimir Dimitrov", Bulgarian Academy of Sciences, Department of Mineralogy and Mineral Resources, Academic Georgi Bonchev str., bl. 24, 1113 Sofia, Bulgaria.

sergeevai@geology.bas.bg

Latinka Hristova. National Museum of Natural History, Bulgarian Academy of Sciences, Department of

Palaeontology and Mineralogy, 1 Tsar Osvoboditel Blvd., 1000 Sofia, Bulgaria. latihristova@abv.bg

Keywords: Bulgaria; Santonian-Campanian; titanosaurian sauropod; bone histology; sauropod hiatus; $x-$ ray diffraction

Submission: 16 April 2018. Acceptance: 18 February 2020.

\section{INTRODUCTION}

Outcropping over large parts of Northern Bulgaria, the Maastrichtian fossiliferous limestones of the Kajlâka Formation (Jolkičev, 1986) yield all of the fossil remains from Mesozoic tetrapods found within the territory of the country so far. These are rare findings and the majority of the fossil material pertains to marine sauropsids, members of the clade Mosasauroidea (Tzankov, 1939; Nikolov and Westphal, 1976; Jagt et al., 2006). Remains from non-avian dinosaurs-a putative ornithomimosaur (Mateus et al., 2010) and a hadrosauroid ornithopod (Godefroit and Motchurova-Dekova, 2010), are also described.

In this report we discuss two relatively small bone fragments of a tetrapod affinity from the Upper Cretaceous coal-bearing sedimentary succession of the Western Srednogorie, the first ever to be found outside the Maastrichtian limestones of Kajlâka Formation. The fragmentary nature of the fossils and the lack of macroscopically observable diagnostic osteological characters, however, preclude any reliable taxonomic identification beyond Tetrapoda. Even though being largely incomplete, considering their size and the age of the sediments from which they originate from, it is likely that the fossils come from a dinosaur. Yet the possibility that the bones pertain to an aquatic sauropsid, or any other type of large Mesozoic tetrapod, cannot be ruled out without detailed analysis.

The usefulness of paleohistology in taxonomic studies of tetrapods is limited (de Ricqlès et al., 2004). This is due to the large morphological and structural diversity of the bone tissues found in vertebrate animals (Francillon-Vieillot et al., 1990)-a result of the interplay between several factors that determine the characteristics of bone tissues, including structural and functional constraints imposed by mechanical stress and body size, climate, physical characteristics of the environment, and phylogeny (Cubo et al., 2005; de Ricqlès et al., 2008; Castanet et al., 2010; Legendre et al., 2013;
Hofmann et al., 2014; Wilson and Chin, 2014). However, the application of paleohistology in taxonomic studies, especially with regards to ornithodiran archosaurs, have proved useful either for establishing the ontogenetic stage of certain fossils in order to ascertain hidden taxonomic diversity at a particular fossil site (Padian et al., 1995; Prondvai et al., 2014a), or for taxonomic identification of bone fragments without clear osteomorphological hallmarks (Hurum et al., 2006; Garilli et al., 2009; Redelstorff et al., 2014 [but see Lomax et al., 2018]). Our contribution aims to further illustrate the usefulness of paleohistology as a method for identifying the taxonomic affinities of extremely fragmentary fossil remains.

In addition to our osteohistology based analysis of taxonomy, the ontogenetic stage of the fossils is assessed and discussed in relation to their small size. Mineralogy and $x$-ray diffractometry analyses of the bone fragments, coupled with comparative study of the prominence and pattern of secondary osteon's radial microcracking in the bones of all Bulgarian non-avian dinosaurs, are used to address various diagenetic and stratigraphic issues with the studied material. The importance of herein reported new fossil material for the Late Cretaceous fossil record in Europe is briefly reviewed in the light of our interpretations of its taxonomy.

\section{HISTORICAL BACKGROUND OF THE STUDIED MATERIAL}

In 2012, a fossilized bone fragment was brought to the Department of Geology, Paleontology and Fossil Fuels, at Sofia University "St. Kliment Ohridski", for identification. It was found ex situ by Mr. Andrey Tzonkov, an amateur fossil hunter, in the geographic locality Vrabchov dol, situated between the villages of Bankya and Vrabcha (near the town of Tran, Pernik district, Western Bulgaria). The bone was discovered about $1.5 \mathrm{~km}$ east of the village of Bankya in deposits of psammitic to 
psephitic size covering the bed of a small stream. Besides invertebrate marine fauna, the Late Cretaceous sediments in the area had previously provided only amber (Minchev, 1958).

After one unsuccessful attempt at localizing the rocks sourcing the fossil, in August 2017 a team from the National Museum of Natural History, Sofia, collected another bone fragment from the coal-bearing sediments near the village of Vrabcha.

Second visit to the fossil site revealed new and more complete vertebrate fossil material, clearly of dinosaurian origin. These fossils are subject of an ongoing large scale study of the fossil site.

\section{GEOLOGICAL SETTINGS}

\section{General Geology and Previous Studies of the Western Srednogorie Zone}

There are three types of Upper Cretaceous rock successions recognized on the territory of Bulgaria, each representing different depositional paleoenvironment, or facies: North European type, Mediterranean type, and Carpathian type (Figure 1.1) (Dabovski et al., 2009). Of these, the Mediterranean type is typical for the rock successions forming the so-called Srednogorie Zone (sensu Ivanov, 2017), which is out-cropping throughout the Srednogorie Mountains (Figure 1.1) and is further subdivided on Western, Central, and Eastern part based on differences in basin characteristics and basin evolution. The fossil remains studied herein come from the westernmost part of the Western Srednogorie Zone of Western Bulgaria (Figure 1.12). During Cretaceous times this zone formed an arc/backarc basin system within the Alpine orogenic belt, composed of a chain of strike-slip and pull-apart basins, in which sedimentary and volcano-sedimentary sequences were deposited.

The Upper Cretaceous rocks in the area overlie with unconformity Upper Jurassic-Lower Cretaceous carbonate sediments (Dabovski et al., 2009). The rock successions in the zone form elongated northwest-southeast strips, in which are present mainly different limestones, marlstones

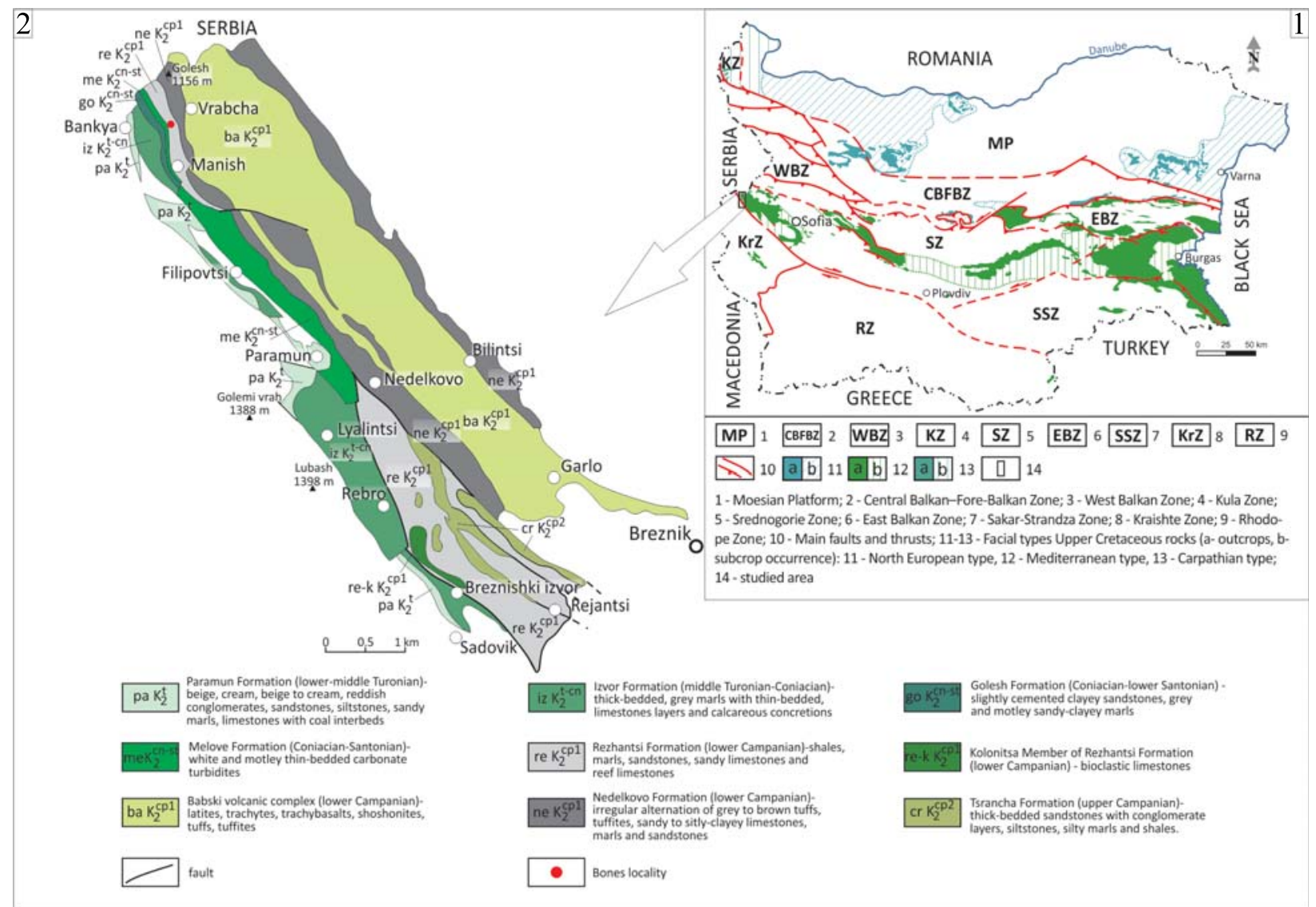

FIGURE 1. General geological settings. 1, Tectonic map of Bulgaria (after Ivanov, 2017); 2, Geological scheme for part of the Western Srednogorie zone and position of the dinosaur bone locality (after Sinnyovsky et al., 2012; simplified). 
and terrigenous lithotypes, as well as volcano-sedimentary successions and small intrusive bodies (Figure 1.2). The sedimentary and volcano-sedimentary complexes in the zone span the TuronianMaastrichtian interval.

Following the earliest geological studies involving the area around the villages of Bankya and Vrabcha (Bonchev, 1923; Zlatarski, 1927), generations of Bulgarian geologists formed the opinion about the existence of a narrow synclinethe Fillipovtsi syncline, in this part of the Western Srednogorie (Zafirov, 1950; Tzankov et al., 1960; Tzankov, 1968; Kostadinov, 1971a, b; Dimitrova et al., 1981; Kostadinov and Tchounev, 1995; Dabovski et al., 2009). The considered age for the rocks forming the syncline spans the interval lower Turonian-Maastrichtian. More recently, Marinova et al. (2010) suggested that the volcano-sedimentary sequence outcropping in the studied area constitute a half-graben structure, with monocline of Turonian and "Senonian" sediments dipping in northeastern direction. Using data from inoceramid bivalves and ammonites, Dochev (2006, 2009, 2015) and Dochev and Ivanov (2008) provide the first detailed paleontological and biostratigraphic studies for this and adjacent parts of the Western Srednogorie.

Sinnyovsky et al. $(2012,2013)$ proposed the first formal lithostratigraphic scheme for the volcano-sedimentary sequences in the Western Srednogorie Zone, one we employ in the current study. These authors define 12 formations and four members, and based on calcareous nannofossils data, suggest an early Turonian to early Maastrichtian age for the proposed formal stratigraphic units.

\section{Geology and Age of the Fossiliferous Section at Vrabchov Dol}

The locality, which has produced the studied herein fossil material, is situated about $1 \mathrm{~km}$ southwest from the village of Vrabcha, in an area known as Vrabchov dol-a gully between the villages of Bankya and Vrabcha (Figure 1.2), and reveals relatively soft and cracked rocks exposed on a small slumped block (Figure 2). The width of the cliff is about $18 \mathrm{~m}$, while the height varies from about $4 \mathrm{~m}$ to 6-7 m. Beds dip to the east at about $25^{\circ}$ in the western part and at $15^{\circ}$ in the central part of the outcrop forming slight syncline flexure. Sediments at the western edge of the cliff are highly tectonically fractured. The relationships of the studied section with underlying and overlying sediments are obscured by soil and vegetation covering and currently remain unresolved (Figure 2.1).
The sedimentary section has a thickness of about $8 \mathrm{~m}$ and is composed of marls of various shades of gray, silicified marls, and coal and coaly shales (Figure 2.2-3). Description of the succession at the outcrop is made from bottom to top: Gray marls more than $1 \mathrm{~m}$ thick. The upper bed surface is uneven. They are covered by $0.30-0.50$ $\mathrm{m}$ coal and coaly shales, black or very dark grey, with ichofossils (worm burrows) and sulfur deposited in the cracks. Clay component increases gradually upwards the last $10 \mathrm{~cm}$, which results in a slight lightening of the sediment. Sediments deposited above are marls abundant in mollusks' detritus and with a thickness of $0.35-0.40 \mathrm{~m}$. The upper part of the bed is intercalated by few thin $(\mathrm{cm})$ layers of clays with organic matter. Next coal and coaly shales bed is very dark grey, lighter than the first one, and is $0.60-0.65 \mathrm{~m}$ thick. The bed is composed of fine layers $(4-5 \mathrm{~cm})$, which form rare synsedimentary folds inside it. A bed of $0.20 \mathrm{~m}$ gray marls enriched in gypsum crystals covers the coaly shales. Above that, a $0.60 \mathrm{~m}$ thick bed of light gray marls with mollusks covered by iron hydroxides is registered. The next sediment is a thick bed $(0.60 \mathrm{~m})$ of solid grayish-beige marls containing organic matter. Above solid marls, a very thick bed $(1.10 \mathrm{~m})$ of gray marls appears. It contains fossilized bones among an abundance of mollusks' detritus and miniature gypsum druses. In this bed two thin and discontinuous coal laminae are observed, and of the upper boundary, clays form few very thin beds (2 cm each). A rusty marl bed with silicified areas comes next. It contains mollusks' fauna and is $0.60 \mathrm{~m}$ thick. The upper bed surface is undistinguished, and with a gradual transition, rusty clays become dark gray marls with a thickness of $1 \mathrm{~m}$. The uppermost bed is represented by dark gray marls with thickness of $0.40 \mathrm{~m}$, which contains remains of mollusks. Sediments are overlaid by soil covering.

Published opinions and estimates on the age of the sedimentary successions in the area are contradictory and differ widely between studies. The coal-bearing layers and coaly shales outcropping in the vicinity of Vrabcha have long been considered to be lower or upper Turonian in age (Zafirov, 1950; Tzankov et al., 1960; Tzankov, 1968; Kostadinov, 1971a, b; Dimitrova et al., 1981; Kostadinov and Tchounev, 1995; Dabovski et al., 2009), based mainly on biostratigraphic data from gastropod fauna and lithological similarities with sedimentary successions with well constrained age, the rocks of the Paramun Formation in particular (Sinnyovsky et al., 2012) (Figure 1.2). 

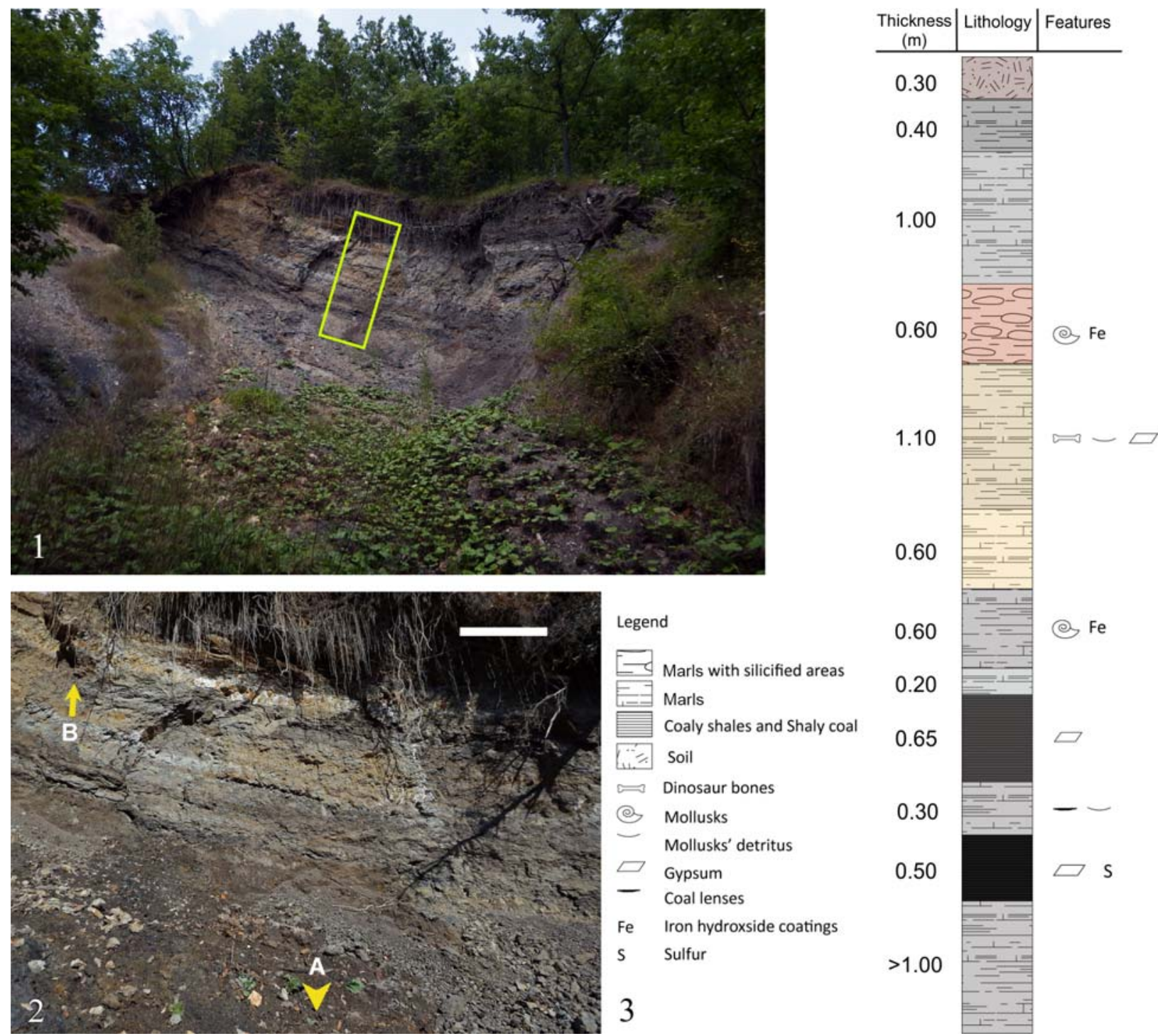

FIGURE 2. Geology, lithology and stratigraphy of the dinosaur bone locality at Vrabchov dol. 1, General view of the fossil-bearing sediments in the gully of Vrabchov dol yielding the dinosaur material. The yellow rectangle marks the sedimentary section illustrated on Figure 2.3; 2 , Detail of the outcrop with position of one of the studied bone fragments (A; specimen NMNHS FR-16) and additional tetrapod remains (B). Scale bar equals $1 \mathrm{~m}$; 3 . Lithostratigraphic column of the Late Cretaceous sedimentary succession outcropping at the locality.

While Dochev (2009) did not do any studies on the fine-grained terrigenous sediments with coal interbeds exposed in this part of the Western Srednogorie, Dochev $(2009,2015)$ suggested middle Turonian-lower Coniacian age for the first $100 \mathrm{~m}$ of the exposed in the gully sediments (Izvor Formation), based on biostratigraphic data derived from inoceramid bivalves. Moreover, the sedimentary rocks cropping-out in the vicinity of the hamlet of Manish (Figure 1.2) (Melove and Rezhantsi formations) span the interval uppermost Coniacian?lower Campanian (Dochev, 2009; Dochev and Ivanov, 2008). Fossil data presented in these stud- ies, along with the pull-apart character of the sedimentary basin in this part of the Western Srednogorie, argue against the presence of a syncline structure exposed in the gully between Bankya and Vrabcha and indicate normal monocline dipping of the sedimentary succession, which means that the previously suggested Turonian age for the sediments in the studied section is groundless and incorrect.

The sedimentary section at Vrabchov dol falls within the geographic range of the Rezhantsi Formation (Figure 1.2). Sedimentary successions included in the formation are formed predominantly 
in shallow marine paleoenvironments and comprise of shales, marls, sandstones, sandy limestones, and reef limestones. Lithology, rock structure, and texture of the sediments exposed in the studied section at Vrabchov dol suggest a more proximal, nearshore to foreshore depositional environment. More distal shallow marine parts of the Rezhantsi Formation are dated to the early Campanian based on calcareous nannofossils (Sinnyovsky et al., 2013).

Unfortunately, as evidenced by published data reviewed above, the exact age affinities of the fossiliferous sedimentary section studied herein remain largely unclear. The available invertebrate macro-fossil data from the section consists of small to medium sized gastropods and bivalves, all occurring in the lower part of the exposed succession, but neither group provides reliable age determination. During the first field trip to Vrabchov dol in 2015, one of us collected small fragment of an inoceramid bivalve from the genus Platyceramus from the upper part of the underlying Melove Formation. The first appearance of this taxon is in lower-middle Coniacian and ranges most probably to the mid-Maastrichtian (Walaszczyk and Cobban, 2006). The older representatives of the genus Platyceramus found in Bulgaria come from Santonian sediments, including a section located west from the hamlet of Manish (Dochev, 2009; Dochev and Ivanov, 2008). Thus, based on the limited fossil data at hand and previously published paleontological results we consider that the age of the studied section potentially falls somewhere in the interval lower Santonian to lower Campanian.

\section{MATERIAL AND METHODS}

\section{Institutional Abbreviations}

Sofia University "St. Kliment Ohridski"-U.S. Museum of Paleontology and Historical GeologyMPHG.

National Museum of Natural History, Bulgarian Academy of Sciences, Sofia-NMNHS.

Geological Institute, Bulgarian Academy of Sciences-GI-BAS.

\section{Fossil Material}

Primary focus of this study are two fossilized bone fragments found in the locality Vrabchov dol, Western Srednogorie, Bulgaria (Figure 3). The fossil material cannot be osteologically identified beyond Tetrapoda.

The original specimen, U.S., $\mathrm{K}_{2} 1586$, is a single diaphyseal fragment (see Results) (Figure 3.1).
The preserved portion of the diaphyseal shaft is straight, $79 \mathrm{~mm}$ in length, and expands slightly on the one side, which results in different cross-sectional shape at each end. In transversal view, the expanded side is sub-triangular, with a width along the long axis of the cross-section of $80 \mathrm{~mm}$, and 55 $\mathrm{mm}$ along the short axis. The other side of the specimen is transversally ellipsoid to slightly egg shaped, with cross-sectional width along the axes of $76 \mathrm{~mm}$ and $52 \mathrm{~mm}$, respectively. Shaft's circumference is $\sim 207 \mathrm{~mm}$. The lack of specific osteomorphological hallmarks, coupled with some microanatomical characteristics described below, indicate mid-diaphyseal position for the bone fragment. No parts of the metaphyses, or the epiphyses, appear to be preserved. Bone surface is smooth, but with fine striations running along the long axis. The fossil is dark ochre to dark brown in colour, with a lighter colouring where the medullar regions are (Figure 3.1). Three thin-sections were prepared from U.S., $\mathrm{K}_{2} 1586$ (Figure 4.1-3). Additionally, the cut surface of the bone was polished so it can be studied in reflected light (Figure 5.1-2). All of the thin-sections are held at MPHG.

The second specimen, NMNHS FR-16, is a partial diaphysis with naturally broken surfaces from both sides and no preserved epiphyses (Figure 3.2). The fossil consists of two pieces. The total length is $77 \mathrm{~mm}$. Due to breakage of part of its side, it is not possible to take measurement of fragment's full width. The width of the preserved part is about $56 \mathrm{~mm}$ and the transversal width at the same place-about $35 \mathrm{~mm}$. In cross-section the shape of the fossil is oval to sub-triangular. The fragment's circumference is $148.68 \mathrm{~mm}$. The surface of the fragment is more or less smooth, with striated texture, similarly to U.S., $\mathrm{K}_{2} 1586$. The colour of the surface patina is ochre to light brown; the compact part of the bone is dark brown, while the material, which infills the zones where cancellous bone is developed, is whitish to pale grey in colour (Figure 3.2). One piece of the bone was thin-sectioned (Figure 4.2). Another piece was used as polished section (Figure 5.3).

Additionally, for comparative purposes-mainly looking for similarities of diagenetic and taphonomic character, we subjected to histological analysis an ornithomimosaurian humerus (NMNHS F31436) described by Mateus et al. (2010). In addition, a partial diaphysis (NMNHS F-31442) and assorted six cortical fragments (collectively given specimen number NMNHS Mos19), which are assumed to be part of the hadrosauroid fossil material described by Godefroit and Motchurova- 

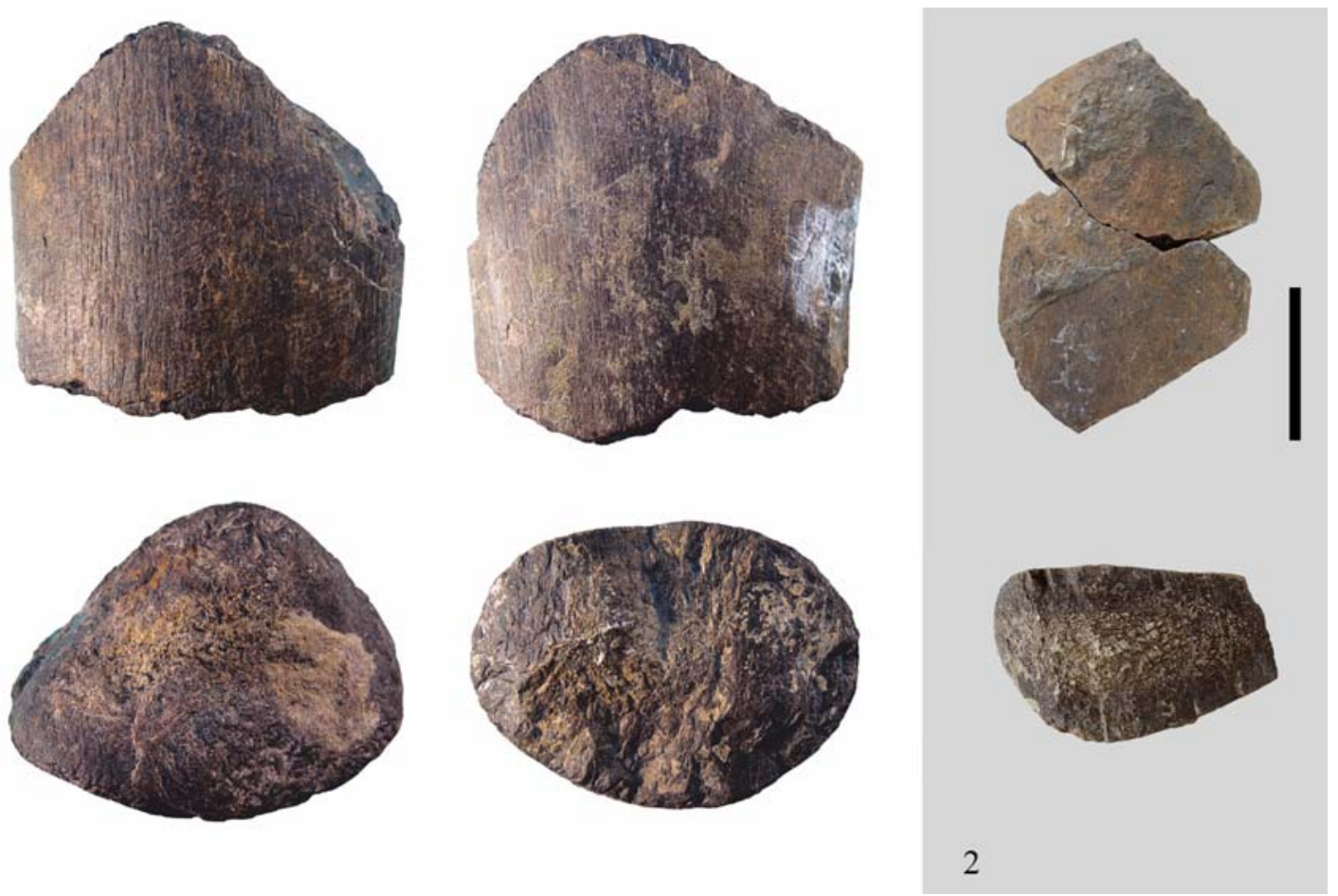

FIGURE 3. Fossilized bone fragments for the Vrabchov dol. 1, Multiple views of specimen U.S., $\mathrm{K}_{2} 1586$, an undetermined long bone diaphyseal fragment; 2 . Specimen NMNHS FR-16, possibly a partial diaphysis of undetermined long bone. Scale bar equals $3 \mathrm{~cm}$.

Dekova (2010), were used. The dinosaurian nature of the latter fossils was confirmed by histological analysis. Some preliminary data on this material is provided by Nikolov (2015). All of the additional fossil material and associated thin-sections are kept in the collection of NMNHS.

General information about all of the studied specimens is provided in Table 1.

\section{Thin-Sectioning and Histological Slide Preparation}

Histological thin-sections are prepared following standard paleohistological methods and procedures (Chinsamy and Raath, 1992; Wilson, 1994; Lamm, 2007) at GI-BAS. An exception is thin-section U.S., $\mathrm{K}_{2}$ 1586-1 which was prepared in the petrographic laboratory of U.S. The fragmentary nature of the specimens precluded application of less invasive methods, such as the one developed by Sander (2000) and Stein and Sander (2009). Limitations imposed by the available fossil material and the technological base at hand required some alterations and adjustments to the standard methods.

U.S., $\mathrm{K}_{2} 1586$ and NMNHS FR-16 were photographed with digital photocamera Canon Power Shot SX200 IS and Fujifilm SL1000, respectively. A molding and casting of U.S., $\mathrm{K}_{2} 1586$ were performed. The cast was produced by "Walltopia" and is currently housed at MPHG along with thin-sections and remaining bone material.

U.S., $\mathrm{K}_{2} 1586$ was embedded in epoxy resin, a mixture of "Epoxa AP-1 Modified" and resin hardener in a ratio 10:1. Embedding was performed under normal room conditions. We observed that the curing of the resin occurs quicker and is more effective at room temperature over $20^{\circ} \mathrm{C}$. The specimen was left to cure for 48 hours before it was removed from the container and handled for sectioning.

Three slides were sectioned from U.S., $\mathrm{K}_{2} 1586$ and one from NMNHS FR-16, all lying in a plane perpendicular to the specimens' long axis, using water-cooled circular saw "Minosekar 2" with diamond-tipped sectorial blade. All cross-sections were boiled in colophony in order to additionally improve their structural integrity. Grinding of the sections was performed manually. The sectioned bone slices were processed with carborundum (silicon carbide) or electro-corundum powder of progressively finer grit-size as follows: $80,220,320$, 600,800 , and 1000.

The ground surface was glued to a glass with thickness of 1.2 millimeters using glue "Crystal- 


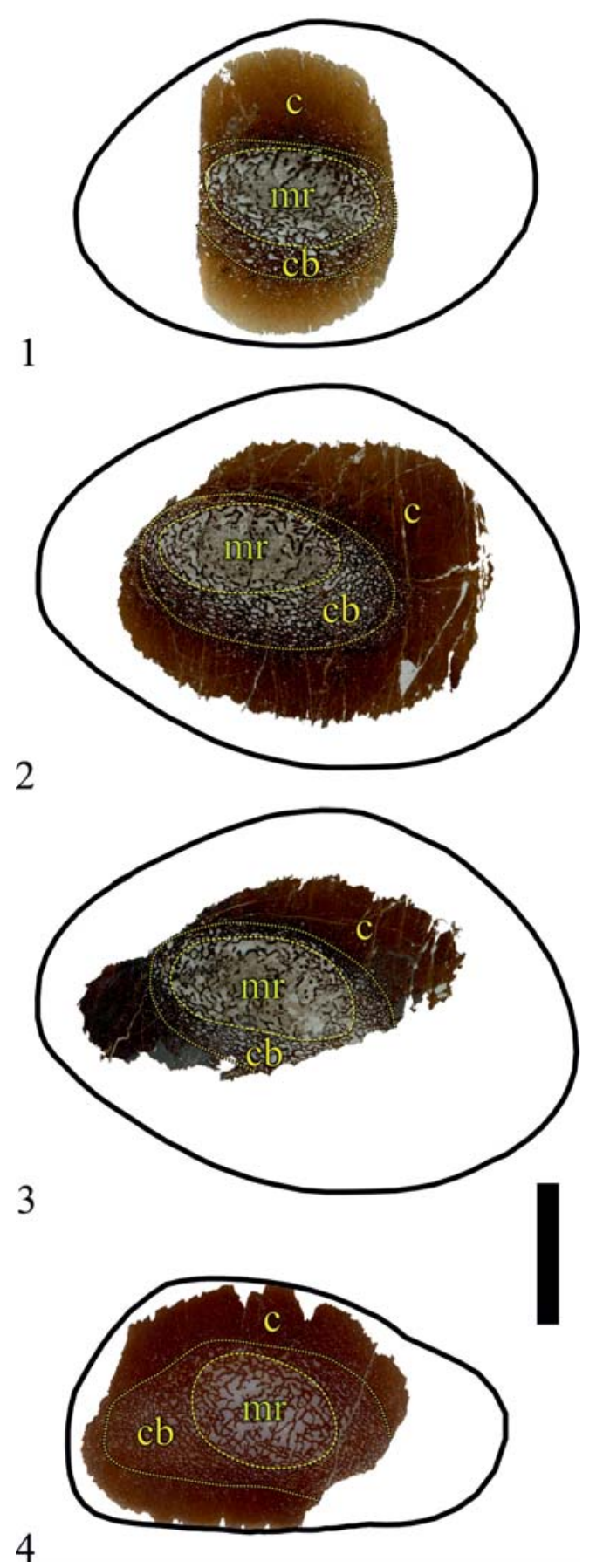

FIGURE 4. Scanned images of studied thin-sections prepared from the Vrabchov dol's fossil fragments, illustrating the degree of cortical loss during preparation, the size of medullary region, and the extent and spatial distribution of cancellous bone tissue. Solid black line illustrates the original cross-sectional form of the fossils. 1 , Thin-section U.S., $\mathrm{K}_{2} 1586-1$; 2, Thin-section U.S., $\mathrm{K}_{2}$ 1586-2; 3, Thin-section U.S., $\mathrm{K}_{2} 1586-3$; 4, A single thin-section from specimen NMNHS FR-16. Abbreviations: c-cortex/compact bone tissue; cb-cancellous bone tissue; mr-medullary region. Scale bar equals 2 $\mathrm{cm}$. bond" and epoxy resin "Moment" by Henkel. Each slide was ground to a thickness which allowed clear observation of specimen's histology. Due to their large size the thin-sections were left "open" with no protective glass mounted over them. In all slides from U.S., $\mathrm{K}_{2} 1586$ the outer cortex and parts of the middle cortex were lost in the process of manual grinding, mostly because of numerous naturally occurring fractures of diagenetic origin in the fossil bone.

\section{Microscopy, Microphotography and Image Processing}

Thin-section examination is conducted on optical microscopes Leica DM2500P and Leica DM750P at magnifications $\mathrm{x} 4, \mathrm{x} 10$, and $\mathrm{x} 40$ for slides U.S., $\mathrm{K}_{2}$ 1586-1, NMNHS F-31436, and NMNHS Mos-19; and on optical microscope Carlzeiss Jena Amplival at magnifications x5.5, x6.3, $\mathrm{x} 12.5$, and $\mathrm{x} 25$ for slides U.S., $\mathrm{K}_{2} 1586-2$, U.S., $\mathrm{K}_{2}$ 1586-3, NMNHS F-31442 and NMNHS FR-16. Thin-sections are studied in transmitted polarized light, successively with parallel and crossed Nicols (or alternatively, plane-polarized, and cross-polarized light). Slides without protective glass were treated with water, or with a couple of drops per slide of baby oil "Johnson \& Johnson", as per the example of Werning (2012), in order to improve the visibility of histological details under microscope. Polished sections are studied on binocular magnifier Leica $E Z 4 D$ at magnifications ranging from $\times 8$ to $\times 35$.

Thin-sections U.S., $\mathrm{K}_{2} 1586-1$, NMNHS F31436, and NMNHS Mos-19 were photographed with camera Leica DFC295 (for Leica DM2500P) and Leica MC120HD (for Leica DM750P), and relevant software Leica Application Suite v.3.3.1 and v.3.0.0, respectively. An optical microscope Axioskop40 Zeiss with camera ProgRes CT3 was used for photographing the histology of slides U.S., $\mathrm{K}_{2} 1586-2$, U.S., $\mathrm{K}_{2} 1586-3$, and thin-sections from specimens NMNHS FR-16 and NMNHS F-31442. Microphotographs for these thin-sections were processed with software ProgRess ${ }^{\circledR}$ CapturePro 2.8.8. Additionally, all thin-sections were scanned on Epson Perfection V33 scanner at resolution of 2400 dpi.

The microphotographs of the studied specimens were digitally processed with Abobe Photoshop CS6 and figures were prepared on CorelDRAW Graphics Suite X7. 

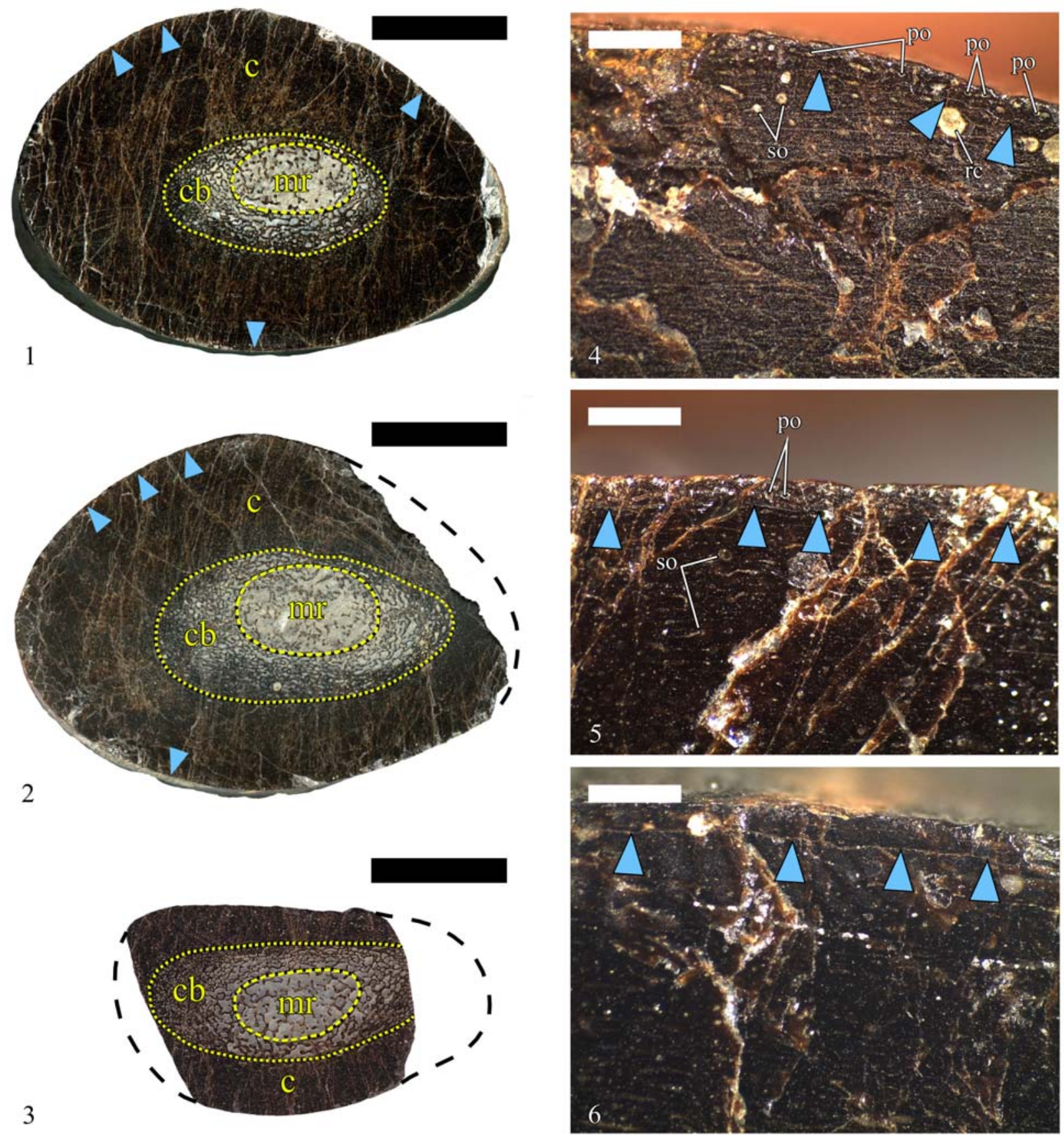

FIGURE 5. Scanned images of the processed cross-section surface of Vrabchov dol's fossil bone fragments and osteohistology of specimen U.S., $\mathrm{K}_{2} 1586$ in reflected light. The dashed line in Figures 5.2-3 illustrates missing parts of the cortex. Blue arrow-heads mark a line of arrested growth (LAG). 1, The original whole bone fragment polished section of specimen U.S., $\mathrm{K}_{2} 1586$ after sectioning for thin-section U.S., $\mathrm{K}_{2} 1586-1$; 2, The whole bone section of U.S., $\mathrm{K}_{2} 1586$ after the further sectioning; 3, Partial bone fragment polished section of specimen NMNHS FR-16; 4-6, Different sections of specimen U.S., $\mathrm{K}_{2} 1586$ bone wall periphery following a single LAG formed sub-periosteally. Some large primary osteons with wide lumina are easily observed above the LAG. Abbreviations: c-cortex/compact bone tissue; cb-cancellous bone tissue; mr-medullary region; po-primary osteon; so-secondary osteon. Scale bar equals 2 cm (Figures 5.1-3); $1 \mathrm{~mm}$ (Figures 5.4-6). 
TABLE 1. Fossil material subjected to histological study.

\begin{tabular}{|c|c|c|c|c|c|c|c|}
\hline Specimen & $\begin{array}{l}\text { Localityl } \\
\text { Formation }\end{array}$ & Taxon & $\begin{array}{l}\text { Skeletal } \\
\text { element }\end{array}$ & $\begin{array}{c}\text { Length } \\
(\mathrm{mm})\end{array}$ & $\begin{array}{c}\text { Circumferen } \\
\text { ce }(\mathrm{mm})\end{array}$ & Thin-section & $\begin{array}{l}\text { Polished } \\
\text { section }\end{array}$ \\
\hline U.S., $\mathrm{K}_{2} 1586$ & $\begin{array}{l}\text { Vrabchov dol/ } \\
\text { Rezhantsi } \\
\text { Formation }\end{array}$ & ?Titanosauria & $\begin{array}{l}\text { diaphyseal } \\
\text { fragment of } \\
\text { undetermined } \\
\text { long bone }\end{array}$ & 79 & $\sim 207$ & $\begin{array}{l}\text { U.S., } K_{2} 1586-1 \\
\text { U.S., } K_{2} 1586-2 \\
\text { U.S., } K_{2} 1586-3\end{array}$ & yes \\
\hline NMNHS FR-16 & $\begin{array}{l}\text { Vrabchov dol/ } \\
\text { Rezhantsi } \\
\text { Formation }\end{array}$ & ?Titanosauria & $\begin{array}{l}\text { undetermined } \\
\text { bone fragment, } \\
\text { possibly part of } \\
\text { long bone } \\
\text { diaphysis }\end{array}$ & 77 & 148.68 & NMNHS FR-16 & yes \\
\hline $\begin{array}{l}\text { NMNHS F- } \\
31436\end{array}$ & $\begin{array}{l}\text { Kajlâka } \\
\text { Formation }\end{array}$ & Ornithomimosauria & $\begin{array}{l}\text { partial left } \\
\text { humerus }\end{array}$ & 94 & 180 & $\begin{array}{l}\text { NMNHS F-31436-a } \\
\text { NMNHS F-31436-b }\end{array}$ & no \\
\hline $\begin{array}{l}\text { NMNHS F- } \\
31442\end{array}$ & $\begin{array}{l}\text { Labirinta cave/ } \\
\text { Kajlâka } \\
\text { Formation }\end{array}$ & ?Hadrosauroidea & $\begin{array}{l}\text { partial } \\
\text { diaphysis }\end{array}$ & 98 & 158 & NMNHS F-31442 & no \\
\hline NMNHS Mos19 & $\begin{array}{l}\text { Labirinta cave/ } \\
\text { Kajlâka } \\
\text { Formation }\end{array}$ & ?Hadrosauroidea & $\begin{array}{l}\text { assorted } \\
\text { cortical } \\
\text { fragments }\end{array}$ & & & $\begin{array}{l}\text { NMNHS Mos19-1 } \\
\text { NMNHS Mos19-2 } \\
\text { NMNHS Mos19-3 } \\
\text { NMNHS Mos19-4 } \\
\text { NMNHS Mos19-5 } \\
\text { NMNHS Mos19-6 }\end{array}$ & no \\
\hline
\end{tabular}

\section{Preferred Paleohistological Terminology and Thin-sections Description}

The paleohistological terminology used in this study largely follows that of Francillon-Vieillot et al. (1990). Recent developments in the understanding of osteogenesis (Stein and Prondvai, 2014), as well as the discovery of modifications of some previously well-understood bone tissues (Benton et al., 2010; Stein et al., 2010; Klein et al., 2012), prompted acceptance and use of new terms "woven-parallel complex" (Prondvai et al., 2014b) and "modified laminar bone" (Klein et al., 2012). We, however, try to avoid application of the latter term in the text below (see Caux et al., 2017). Because of its historical importance and its wide use in the paleohistological literature, wherever it is mentioned in the "Discussion" section of this study, the term "fibrolamellar complex" is restricted only to bone tissue of periosteal origin, characterized by woven-fibered bone scaffolding and primary osteons.

Osteohistological description of studied thinsections progresses in periosteal direction, from the medullar region towards the periosteum, with cortical bone tissues of periosteal origin described first, and secondary bone tissues (Haversian bone) second. For each bone tissue, details of the characteristics of bone scaffolding, vascularity and vascular architecture, and osteocyte lacunae morphology are provided.

\section{Assessing Ontogenetic Stage of Studied Material}

Changes in the nature of the bone scaffolding, changes in the vascular organization, density, and size of primary osteons, presence of growth lines (modulations, annuli, lines of arrested growth, and polished lines), and formation of external fundamental system (also known as "outer circumferential layer") are evaluated in order to assess the ontogenetic stage of the Vrabchov dol fossils. The Histologic Ontogenetic Stages (HOS) model developed by Klein and Sander (2008), and later expanded by Stein et al. (2010), is applied to the studied material. Because the fossils have shown to be heavily affected by extensive Haversian remodeling, the recently established Remodeling Stages (RS) model of Mitchell et al. (2017) is also used. The RS model expands on the HOS model and allow for better distinguishment of relative ontogenetic state of senescent individuals. Even though the RS method is established on the base of sauropod bone histology, it holds the potential to be applied to a variety of taxa which long bones experience strong secondary remodeling and development of Haversian bone (Mitchell et al., 2017, 338-339).

\section{X-ray Diffraction Measurements}

Powder x-ray diffraction was used for phase identification and crystallite size determination of 
bone apatite of five fossil bones specimens: U.S., $\mathrm{K}_{2} 1586$ and NMNHS FR-16 from Vrabchov dol and dinosaur fragments NMNHS F-31442, NMNHS Mos19-2, and NMNHS Mos19-3 from Labirinta cave. The Labirinta cave specimens were selected for having cortex with well developed laminar bone tissue. All samples were carefully grinded in agate mortar with alcohol, to avoid insertion of stress and better homogenization, prior x-ray examination.

$X$-ray powder data were collected using a Siemens Crystalloflex high-voltage generator with incorporated HUBER Image Plate Guinier Camera G670, working in transmission asymmetric mode (Guinier geometry). Diffraction measurements were carried out with fine focus ceramic tube $(\mathrm{Cu}$ anode), under $40 \mathrm{kV}$ and $40 \mathrm{~mA}$ operating conditions and $\mathrm{Ge}$ monochromator placed on the primary beam, providing pure $\mathrm{CuKa}_{1}$ radiation $(\lambda=$ $1.540598 \AA$ ). Data collection was performed in the angular range from 4 to 100 degrees two theta and step size of $0.0052 \theta$, simultaneously. The exposure time was 30 minutes for every sample with six scanning runs of the readout system, which brought about to collection of high quality diffractograms.

Collected diffraction data were analyzed with Match! software package for phase identification, by CRYSTAL IMPACT, Bonn, Germany, with incorporated ICDD PDF-2 and COD databases, to determine the presence and the quantities of the corresponding crystalline phases. Semi-quantitative phase analysis is performed using the "Reference Intensity Ratio" method (RIR-method), based on comparison of the intensity scaling factors of the identified phases with reference to a "Corundum standard", so-called I/lc factors.

For crystallite size estimation, LaB6 (NIST SRM 660) was used as a standard, to separate the contribution of the instrument to the peak broadening $\left(\mathrm{FWHM}=\right.$ Full Width at Half Maximum $\left.{ }^{\circ} 2 \theta\right)$ from the actual contribution of the sample. The FWHM values of the latter are then used in the Scherrer formula to calculate an estimate for the average crystallite size (coherently diffracting domains) of the corresponding phase/compound along different crystallographic directions.

\section{RESULTS}

\section{Osteohistology of U.S., $\mathrm{K}_{2} 1586$ in Transmitted Light}

The specimen has a thick cortex of compact bone, with thickness varying between $16 \mathrm{~mm}$ and $26 \mathrm{~mm}$, and an absence of free medullary cavity
(Figure 5.1-2). The compacta consists largely of dense secondary (Haversian) bone tissue. The medullar region is relatively small, ellipsoid in shape, and slightly offset from the center of the bone's cross-section. Its width varies between 16 $\mathrm{mm}$ and $30 \mathrm{~mm}$ along the axes of the ellipsoid. Cancellous bone tissue infills the medulla (Figures 4.1-3, 5.1-2).

The cancellous bone tissue is unevenly developed inside the medulla, and exhibits differing morphologies in its opposing sides (Figure 4.1-3). One side of the medullary region has better developed, finer cancellous tissue, which gradually transitions to the compact cortical bone. Trabecular thickness increases, while intertrabecular spaces reduce in size, periosteally. Spaces with clearly elongated form appear to be spatially arranged with their long axis sub-parallel or parallel to the periosteal surface. On the opposing side of the medulla the cancellous tissue is coarser, with larger trabeculae, which are oriented towards bone's center. Resorption cavities and intertrabecular spaces are fewer, but larger in size.

The bone trabeculae consist of avascular endosteal lamellar tissue. The abundance of osteocyte lacunae in the endosteal bone varies between thinsections, but their size, morphology, and spatial alignment are fairly constant. The lacunae are large, moderately to strongly elongated, and aligned more or less parallel to subjacent ones. Perimedullary, the trabeculae involve secondary osteons of the Haversian bone of the deep cortex. No reversion line to mark the boundary between cortical bone and medullary cancellous bone is present in any of the studied slides.

Primary cortical bone is made of highly vascularized bone tissues with a variable degree of spatial organization of the bone matrix (Figure 6.1-6). These bone tissues are preserved in spatially discrete areas of the studied slides, or more often appear as interstices between secondary osteons of the Haversian bone, which composes the bulk of the compacta. The bone matrix of the tissues in the deep cortex is dominated by woven bone (Figure 6.1 ), while in the outer two-thirds of the cortex the bone scaffolding is predominantly parallel-fibered in character (Figure 6.2-6). Primary bone tissues are moderately to highly vascularized. Vascular structures are primary osteons of longitudinal, or less often circumferential type, with latter varying in length and present at mid-cortical levels (Figure 6.1-6). Due to the small amount of preserved primary bone tissue, it is difficult to ascertain with confidence, but it appears that the size of primary 

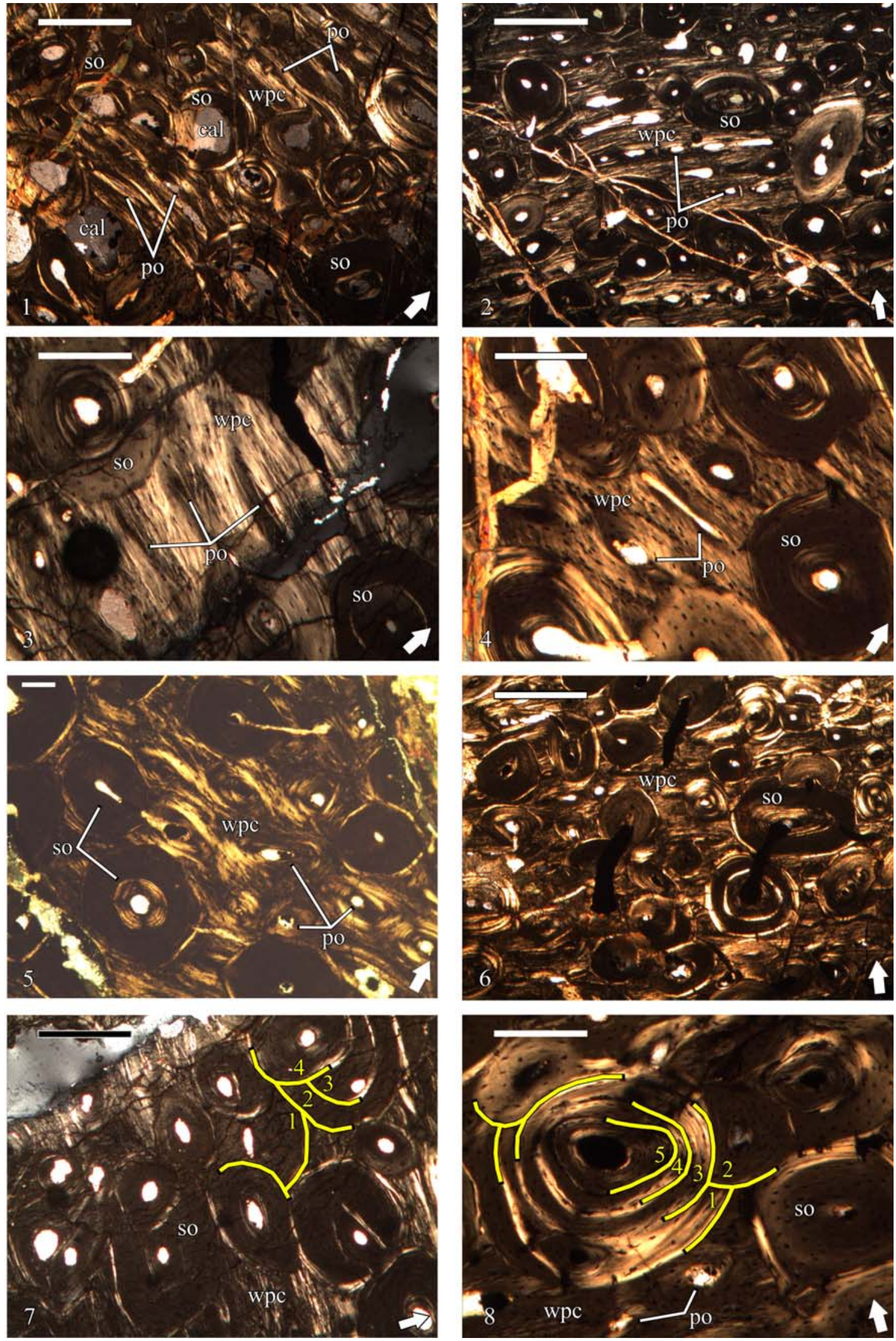

FIGURE 6 (caption on next page). 
osteons increases periosteally. Some of the longitudinal osteons exhibit slight flattening parallel to the bone surface. In regards of vascular architecture, the primary bone is of laminar type, with short circumferential osteons and/or longitudinal primary osteons arranged in circumferential rows (Figure 6.1-5). Based on their characteristics, the tissues of the periosteal bone can be defined as a wovenparallel complex. At deep cortex, primary bone tissues include numerous, large, morphologically diverse osteocyte lacunae with a moderate degree of spatial organization. Lacunae reduce in numbers, show generally more elongate morphology, and higher organization in periosteal direction.

The whole cortex is affected by intensive processes of bone remodeling resulting in the formation of dense Haversian tissue (Figure 6). Degree of remodeling appears to be higher in that half of the bone cross-section adjacent to the region with coarser cancellous bone. In these zones the secondary osteons exhibit pronounced variation in size of different individuals, with larger osteons occurring more frequently perimedullary. Regarding the ontogenetic state of the secondary osteons (degree of infilling with osteonal bone tissue), they vary from incipient (very few deposited bone lamellae) to mature (almost completely infilled osteons with small lumen) at deep cortical levels (Figure 6.1), while those in the mid-cortex exhibit more uniform ontogenetic characteristics (Figure 6.2, 6.57). However, processes of bone resorption and secondary osteon formation at death were active even in the outer half of the cortex, as evidenced by the presence of small erosional rooms and scattered incipient Haversian osteons. It is worth noting that not all osteons of the Haversian bone tissue show clear lamellar structure-some individuals are characterized by bone tissue with mass anisotropic optical features indicative of parallel-fibered bone
(Figure 6.8). Individual secondary osteons sometimes show unusual features, like the presence of two lumina instead of a single canal, or large Haversian osteon of earlier generation containing osteons of later generations (Figure 6.8). Bone tissue infilling secondary osteons generally shows numerous osteocyte lacunae, but their numbers dwindle towards the bone surface. Lacunae with oval or slightly ellipsoid morphology are rare and restricted to the deep cortex, while those with strongly elongated appearance dominate. While in most secondary osteons osteocyte lacunae spatial organization generally follows the centripetally deposited bone lamellae, there are individuals infilled with tissue characterized by lacunae forming, more or less, parallel rows. Radial cracking of secondary osteons is not pronounced when present and occurs relatively rarely in the Haversian bone of U.S., $\mathrm{K}_{2} 1586$. Up to four osteonal generations are evident in outermost preserved parts of the cortex (Figure 6.7). In slide U.S., $\mathrm{K}_{2}$ 1586-1 locally at mid-cortical levels there are five generations of secondary osteons (Figure 6.8).

No growth marks of any kind are observed in studied thin-sections. Even if originally present, the extensive Haversian remodeling has erased all traces of periodic fluctuation in primary bone depositional rates.

\section{Osteohistology of U.S., $\mathrm{K}_{2} 1586$ in Reflected Light}

Observations of the specimen in reflected light concentrated mostly on the histological characteristics of the outer cortex.

Primary bone tissue is highly vascularized and remains this way, up to the periosteal surface. Primary osteons are longitudinal, with some individuals slightly flattened transversely to the periosteum

FIGURE 6 (on previous page). Osteohistology of specimen U.S., $\mathrm{K}_{2} 1586$, a diaphyseal fragment of a putative titanosaurian long bone, in transmitted cross-polarized light. Arrow in the lower right corner of each image indicates the direction of the periosteum. 1, Primary bone in the deep cortex consisting of highly vascularized tissues of the wovenparallel complex (sensu Prondvai et al., 2014), with strong presence of woven component in the bone scaffolding and laminar organization of the primary osteons. Secondary osteons of various size and degree of infilling are developed over the primary tissues; 2 , Primary bone tissues in the mid-cortex. The tissue is clearly anisotropic and indicates high spatial organization of the bone scaffolding; 3, High magnification image of the primary bone tissues in the mid-cortex, showing optically highly anisotropic laminar bone; 4, Same bone tissue type as 3 but illustrating different area of the mid-cortex; 5, Primary bone tissues in the outer half of the cortex in thin-section U.S., $\mathrm{K}_{2} 1586-2$. Primary osteons exhibit slightly more irregular organization but it can still be described as laminar; 6 , Numerous secondary osteons of at least two generations at mid-cortical levels in area less affected by Haversian remodeling; 7 , Four generations of secondary osteons in the outer half of the cortex; 8, Five generations of secondary osteons in the deep cortex. Notice the formation of numerous generations of secondary osteons inside the boundaries of earlier, much larger secondary osteon. Abbreviations: cal-calcite; po-primary osteon; so-secondary osteon; wpc-woven-parallel complex (sensu Prondvai et al., 2014). Scale bar equals 1-2, 6-7-500 $\mu \mathrm{m} ; 3-4,8-200 \mu \mathrm{m} ; 5-100 \mu \mathrm{m}$. 
(Figure 5.4). In terms of vascular architecture, osteons are organized laminary, forming concentric rows. Subperiosteally there is a line of arrested growth (LAG), which appears to mark a change in primary bone vascular characteristics (Figure 5.46 ). Below the LAG primary osteons seem to be sparser, while above it they are in larger number, exhibit a generally larger size, and have wider lumina. This change in the vascular organization resembles the condition typical for an annulus, but without observations in transmitted polarized light we cannot confirm its presence. Characteristics of the vascular system indicate that at the time of death, bone was still actively growing appositionally, albeit at a slower pace.

The secondary remodeling is intensive, as in studied thin-sections, with dense Haversian bone tissue making most of the outer cortex (Figure 5.45). Secondary osteons reach the periosteum, with at least two generations of them being present in outermost cortex.

As mentioned above, a LAG is formed subperiosteally. It can be traced through a bone's cross-section, but in some areas it is completely erased by secondary osteon formation. Morphologically, the LAG is straight, but locally it shows a markedly undulating shape (Figure 5.4-6). Undulations are probably a result of local resorption of bone tissue along the periosteum during the period of arrested growth.

\section{Osteohistology of NMNHS FR-16 in Transmitted Light}

At the point of sectioning, specimen's transverse section is ellipsoid, slightly expanded on the one side. The bone has a thick, compact cortex, and similarly to U.S., $\mathrm{K}_{2} 1586$ does not have free medullar cavity. The compacta consists almost entirely of dense Haversian bone tissue (Figure 4.4).

The medulla is infilled with bone trabeculae forming coarse cancellous bone, which changes periosteally into fine cancellous bone, and then into the compact bone of the inner cortex. Unlike in U.S., $K_{2} 1586$, the features of the cancellous bone in NMNHS FR-16 are more uniform throughout the cross-section, and the transition to compact cortical bone appears to be more gradual (Figure 4.4). Yet in some regions the transition could still be defined as more abrupt compared to the rest of the bone. Intertrabecular spaces and erosional rooms are of varying sizes and shapes, with former decreasing in outwards direction, while the latter changing from highly irregular, to ellipsoid, and oval. Ellipsoid spaces are oriented parallel to the periosteum. Resorption cavities at the transition towards the cortex are developed over secondary cortical tissues, as evident by the cutting relationships with secondary osteons. The boundaries of resorption cavities are smooth and most of them are partially infilled with bone tissue. Bone trabeculae in the medullar region are made of endosteal lamellar, locally-parallel-fibered, bone tissue. Perimedullary, trabeculae involve remnants of Haversian bone. Osteocyte lacunae of the medullar cancellous bone are less numerous and with markedly more elongated morphology in comparison to lacunae in the medullar periphery. No reversion line is present between medullar region and cortex.

The formation of dense Haversian bone has erased almost entirely the primary cortical tissues. Remains of periosteal bone reveal between secondary osteons as small interstices of tissue characterized by strong optical anisotropy (Figure 7.12). Locally at mid and outer cortical levels, there are slightly larger areas which preserve primary bone tissue, but everywhere the bone exhibits the same characteristics-optical anisotropy, bone crystallites arranged parallel to the periosteum, and limited data on the degree and type vascularization. The few primary osteons which can be observed are of longitudinal type (Figure 7.2). The apparent poor vascularity of the primary bone tissue, especially in the outer half of the cortex where it is most easily recognized, most probably reflects the small amount of preserved tissue, but may also be a result of generally low vascularity, or deposition of these tissues late through the ontogeny. Osteocyte lacunae are moderately abundant and of elongated shape.

The secondary remodeling is more pronounced than in U.S., $\mathrm{K}_{2} 1586$, with dense Haversian bone extending up to the periosteal surface (Figure 7.1-2). Size of secondary osteons reduces outwards. Generally, Haversian systems in outer cortex are mature, or with at least half their volume infilled with bone lamellae (Figure 7.3). Throughout the cortex the processes of bone remodeling were still active at the time of death as indicated by the presence of resorption rooms and incipient secondary osteons. Osteonal tissue osteocyte lacunae are numerous, mostly moderately to slightly elongate in shape, with oval lacunae more frequent in the deep cortex, near the medullar region. At least four generations of secondary osteons are observable through the whole thickness of the cortex of NMNHS FR-16 (Figure 7.3). Inside large osteons of earlier generations are formed smaller second- 

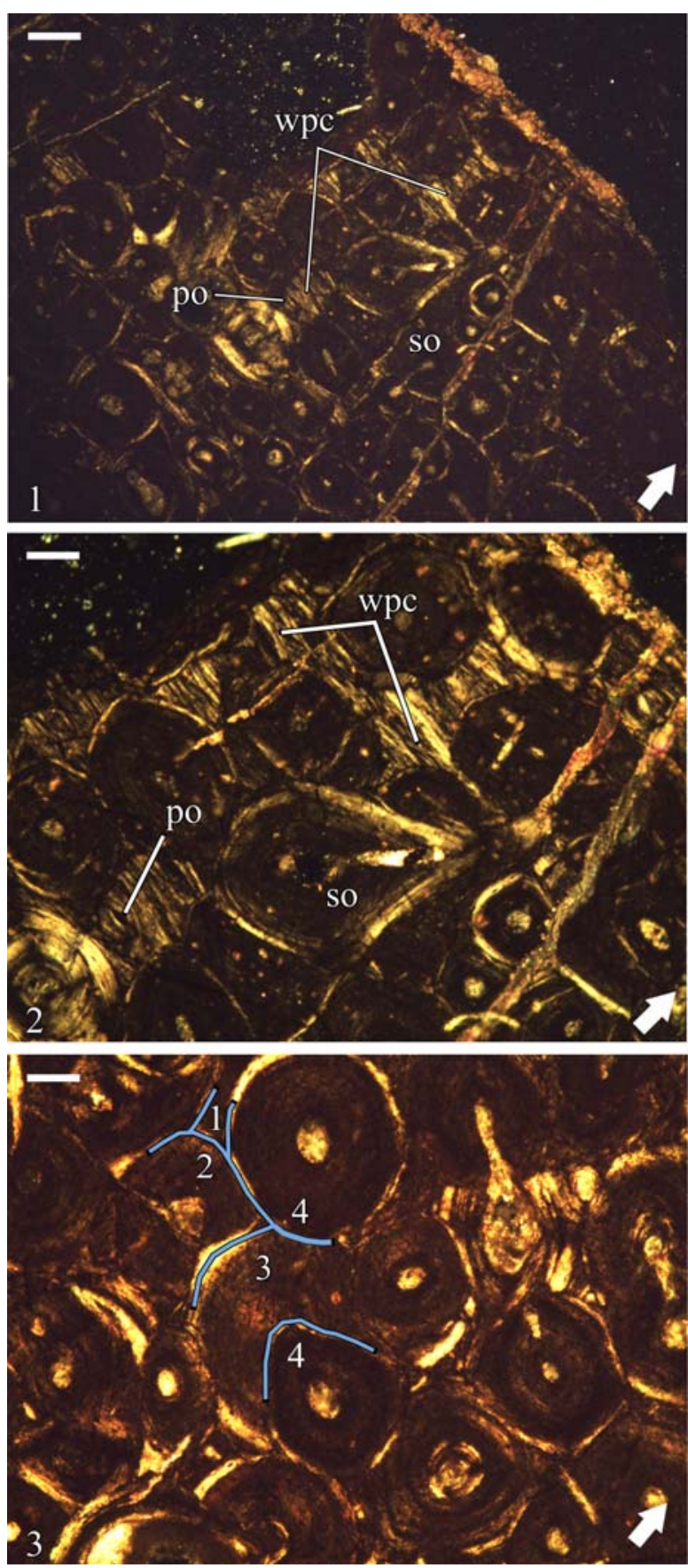

FIGURE 7. Osteohistology of specimen NMNHS FR-16, a putative titanosaurian long bone fragment, in transmitted cross-polarized light. Arrow in the lower right corner of each image indicates the direction of the periosteum. 1 , Heavily remodeled outer cortex with anisotropic primary bone tissues preserved as interstices between secondary osteons; 2, Same area with preserved primary cortex as 1, but at higher magnification. Primary osteons appear to be longitudinal; 3, Dense Haversian bone with 4 generations of secondary osteons in the outer third of the cortex. Abbreviations: po-primary osteon; so-secondary osteon; wpc-woven-parallel complex. Scale bar equals $1-200 \mu \mathrm{m} ; 2-3-100 \mu \mathrm{m}$. ary osteons, sometimes up to three individuals. Formation of radial microcracks in secondary osteons is present, but although microcracks are numerous locally, they cannot be described as particularly abundant in general.

NMNHS FR-16 shows no signs of growth marks, which is expected, given the extreme degree of cortical bone remodeling.

\section{Osteohistology of NMNHS FR-16 in Reflected Light}

The study of NMNHS FR-16 bone histology in reflected light confirms observations conducted in transmitted light and adds no additional information regarding specimen's histological features.

\section{Ontogenetic Status of the Vrabchov dol Material}

Bone histology of specimen U.S., $\mathrm{K}_{2} 1586$ shows a combination of features typical of tissue types E, F, and G, sensu Klein and Sander (2008), which refers to HOS 12-13. Based on maximum number of secondary osteon generations observed in different parts of the cortex, an RS 13 can be assigned for the specimen. The cortical bone of NMNHS FR-16, which is remodeled throughout by four generations of secondary osteons, responds to tissue type $\mathrm{H}$ and HOS 14 of Stein et al. (2010) and RS 12. Differences in HOS and RS between specimens could be explained with variability in the histology of different skeletal elements and not with different relative ontogenetic age. Such intraskeletal variation in secondary remodeling has been reported for various dinosaurian taxa, among them Hypacrosaurus (Horner et al., 1999), Maiasaura (Horner et al., 2000), Plateosaurus (Klein and Sander, 2007), Apatosaurus (Curry, 1999), Phuwiangosaurus (Klein et al., 2009), Ampelosaurus (Klein et al., 2012), and to a lesser degree for Alamosaurus (Woodward and Lehman, 2009). The process of bone remodeling and Haversian bone formation can be related to different factors (Francillon-Vieillot et al., 1990), but recently it has been hypothesized that smaller skeletal elements, and/ or non-weight bearing bones, are prone to experiencing a higher degree of remodeling due to interrelations between bone-specific growth rates and whole-body metabolic rates (Padian et al., 2016). If this hypothesis is correct, then it is expected for the smaller NMNHS FR-16 to show a lesser amount of preserved primary tissues and more uniform in its characteristics Haversian bone, as actually observed. 
Based solely on HOS and RS, it can be hypothesized that both bone fragments come from individuals that have reached, or are close to reaching, skeletal maturity and thus-adult size. However, the presence of primary bone tissue with large primary osteons in the outermost cortex of U.S., $K_{2} 1586$, indicative of still active growth, shows that this might not be the case, and further analysis is warranted to accurately assign an ontogenetic state for the specimen. Indeed, extreme bone remodeling observed in some taxa, especially if present early in ontogeny, limits the applicability of HOS and the degree of Haversian remodeling as an ontogenetic indicator (Stein et al., 2010; Klein et al., 2012; Curry Rogers et al., 2016).

\section{Osteohistology of the Bulgarian Ornithomimosaur, with Focus on the Secondary Bone Tissues}

Our histological examination of specimen NMNHS F-31436, partial humerus of a putative ornithomimosaur, confirms the specimen's ontogenetic interpretation of Mateus et al. (2010), but differs in its reasoning-we conclude that the humerus belongs to an adult individual based on: (1) presence of endosteal bone tissue, locally two generations of it, lining the free medullar cavity, indicative of termination of medullar expansion (Figure 8.1); (2) formation of dense Haversian bone tissue throughout the cortex, up to the periosteal surface (Figure 8.2); and (3) existence of what appears to be incipient external fundamental system, histological feature marking attainment of skeletal maturity (Figure 8.2). However, contra Mateus et al. (2010), we couldn't observe fibrolamellar bone, as in the traditional definition of the term, in any of the studied two thin-sections. Primary bone tissues, where present, show high lamellar component in the bone scaffolding (Figure 8.3-4).

Processes of secondary remodeling in NMNHS F-31436 are intensive and result in dense Haversian bone reaching the periosteal surface (Figure 8.2). The size of the secondary osteons varies considerably between individuals, but there is a weakly expressed trend towards concentration of osteons of larger size in the deep cortex. The majority are mature individuals. Osteonal lamellar bone is characterized by osteocyte lacunae with pronounced fusiform morphology. The number of osteocyte lacunae is low. There are five generations of secondary osteons in the deep cortex, while the number of generations in the outer cortex is four (Figure 8.3). Some secondary osteons show development of radial cracks (Figure 8.4).

\section{Brief Description of the Osteohistology of the Bulgarian Hadrosauroid}

Originally thought to belong to a marine sauropsids (Jagt et al., 2006), most of the fossil material from the Labirinta cave turned out to be of a hadrosauroid dinosaur (Godefroit and MotchurovaDekova, 2010). For this reason we evaluated whether or not the histology of all sampled specimens fits what is expected of dinosaur bones before any futher study. We confirm the presence of compact cortical bone, highly vascularized tissues of the woven-parallel complex with mostly laminar organization of the vascular system, and sometimes intensive bone remodeling in all of the studied by us material. These histological features are in agreement with the osteohistology of nonavian dinosaurs, and hadrosauroids in particular (Horner et al., 1999, 2000; Vanderven et al., 2014).

The primary bone of all studied fragments is highly vascularized with the bone scaffolding showing a variable degree of spatial organization (Figure 9). Although the woven component dominates in the deep parts of the cortex, the bone matrix of the middle and outer cortex is generally parallelfibered in nature as evidenced by the strong anisotropic appearance of the bone tissues (Figure 9.24). The primary osteons exhibit variable spatial organization both within and between specimens, with longitudinal, reticular, and plexiform tissues all present. Most common, however, is the laminar bone, which locally grades into sub-plexiform (Figure 9.4).

All of the studied thin-sections, except for NMNHS Mos19-1, NMNHS Mos19-2, and NMNHS Mos19-6, show development of secondary bone tissue (Figure 10). In NMNHS Mos19-1 and NMNHS Mos19-2 scattered individual secondary osteons are found, and while in NMNHS Mos19-2 locally they are in higher numbers, even in the outer cortex, no Haversian bone is formed (Figure 10.1-2). Specimens NMNHS Mos19-3, NMNHS Mos19-4, and NMNHS Mos19-5 show intensive Haversian remodeling, which extends to the periosteal surface, but is spatially limited in lateral direction (Figure 10.3-6). The transition towards the bone tissues of the primary cortex is generally abrupt, with small number of scattered secondary osteons formed in cortical areas not strongly affected by the remodeling. Remodeling and formation of Haversian bone is most prominent in specimen NMNHS F-31442, where almost all of 

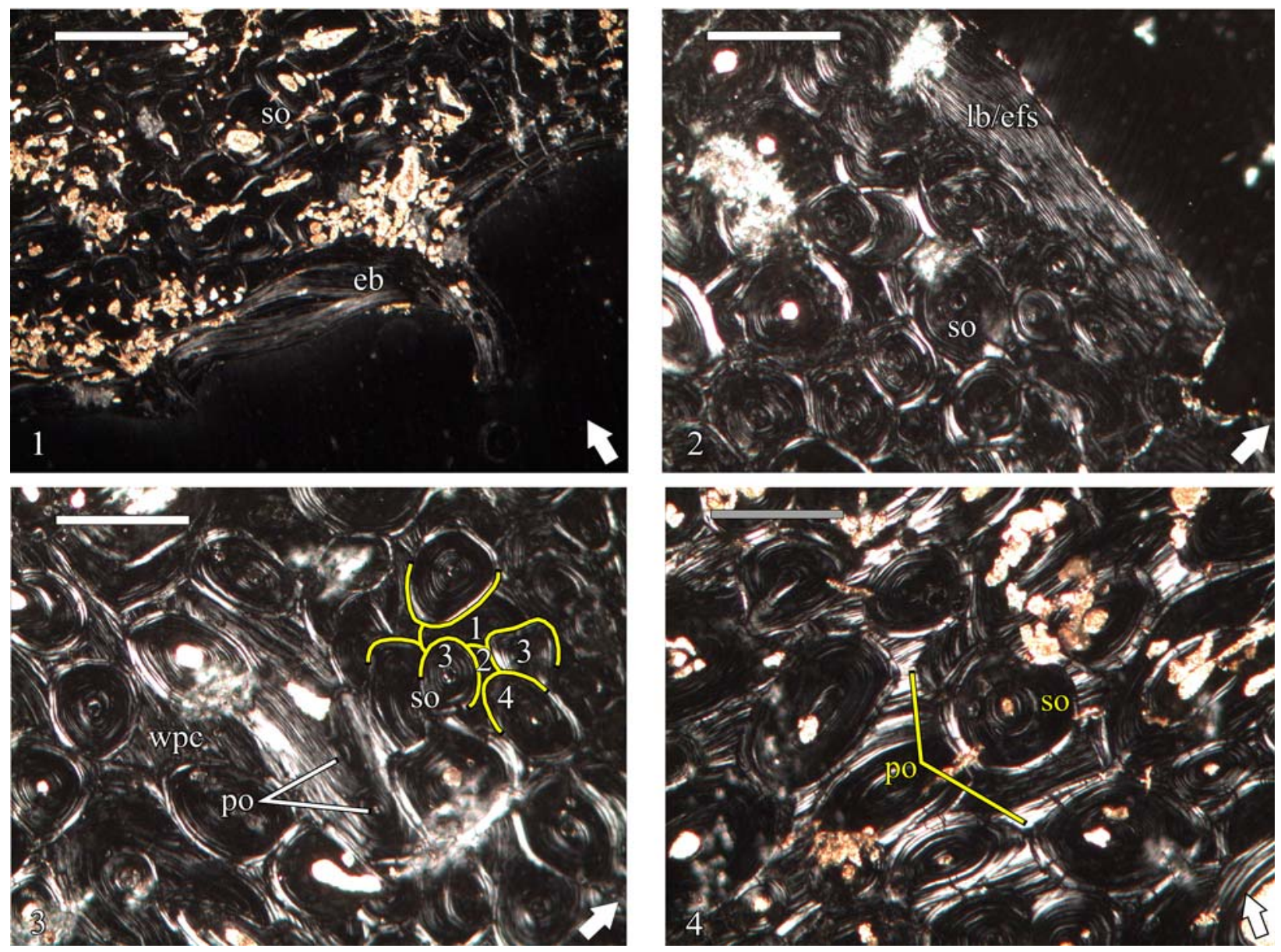

FIGURE 8. Osteohistology of the Bulgarian ornithomimosaur, specimen NMNHS F-31436-a partial left humerus, in transmitted cross-polarized light. Arrow in the lower right corner of each image indicates the direction of the periosteum. 1, Endosteal bone lining the medullary cavity and dense Haversian bone in the inner cortex; 2, Dense Haversian tissue extending up to the outermost cortex and sub-periosteally deposited lamellar primary bone, which probably represents incipient external fundamental system; 3, Interstices of laminar primary bone tissue with relatively organized bone scaffolding and longitudinal primary osteons preserved between the numerous densely packed secondary osteons. Up to 4 generations of secondary osteons can be recognized on the image; 4 , Interstices of preserved primary bone tissues. Abbreviations: eb-endosteal bone; efs-external fundamental system; Ib-lamellar bone; po-primary osteon; so-secondary osteon; wpc-woven-parallel complex. Scale bar equals 1-500 $\mu \mathrm{m} ; 2-4-200 \mu \mathrm{m}$.

the primary bone tissue is replaced by dense Haversian bone (Figure 10.7-8).

In all specimens, secondary osteons show variation in the degree of centripetal bone lamellae infill and in size. Individuals from later generations of osteonal formation are generally of small size. In addition, smaller osteons are more frequent in outer parts of the cortex. Specimens NMNHS Mos19-3 and NMNHS Mos19-4 are peculiar for having secondary osteons, which exhibit markedly different histology, in terms of tissue and cellular features, between generations (Figure 10.3, 10.5). The maximal number of secondary osteon generations observed in the studied specimens is five for NMNHS F-31442, and at least three (but probably more) for NMNHS Mos19-3, NMNHS Mos19-4, and NMNHS Mos19-5.

Compared to the fossils from Vrabchov dol and the ornithomimosaurian humerus, the radial microcracking of the secondary osteons in all of the hadrosauroid material is much more frequent and more prominent-the cracks appear to be more open and larger in size.

\section{Patterns of Secondary Osteon Microcracking}

The process of bone fossilization, and of Haversian bone tissue in particular, is complex, but understudied and in many ways poorly understood (Pfretzschner, 2004). The formation of specific radially oriented microcracks in the secondary 

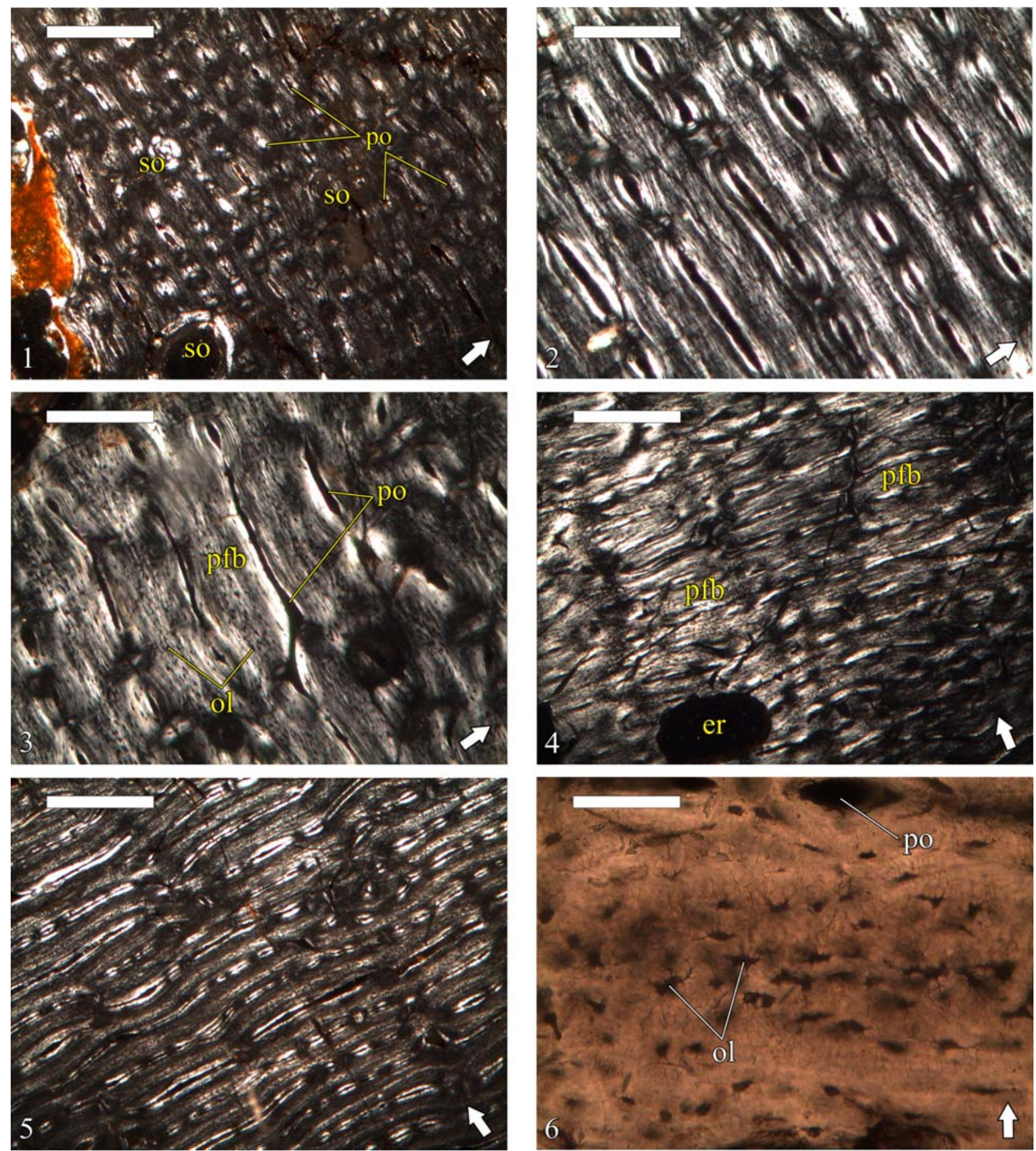

FIGURE 9 (caption on next page). 
osteons is typical for the early diagenesis of Haversian bone fossilized in aquatic environments (Pfretzschner, 2000, 2004). Because the processes leading to the formation of these microcracks are dependent both on the $\mathrm{pH}$ of the environment and the water/diagenetic fluid availability (Pfretzschner, 2004), it can be hypothesized that bones buried and fossilized in different environments, under different conditions, and having undergone different diagenetic history will exhibit differences in the patterns and frequency of radial microcracking of the Haversian bone.

Geochemical data shows that the ornithomimosaurian and hadrosauroid fossil material excavated from the limestones of the Kajlâka Formation have contrastingly different taphonomic and diagenetic history (Mateus et al., 2010; Godefroit and Motchurova-Dekova, 2010). These differences appear to be reflected in the overall preservation of histological details (it is greater in the Labirinta cave's fossils) and in the patterns of microcracking of secondary osteons. The development of microcracks is more frequent in the hadrosauroid Haversian bone in comparison with the ornithomimosaurian humerus (NMNHS F-31436), with fractures which in general appear to be larger in relation to the size of the secondary osteon, and usually more open (wider) (Figure 11.1-4).

In contrast, the two bone fragments from Vrabchov dol exhibit a notably consistent high degree of preservation of histological detail, similar coloration of the bone tissues under microscope, and a practically identical pattern of radial microcracking of the secondary osteons-in both specimens, microcracks are relatively rare, short in comparison with the size of the osteon, and appear more or less as thin lines (Figure 11.5-8). The observed consistencies possibly hint at fossiliza- tion in the same environment, albeit under slightly different conditions as evidenced by the mineralogical data described below.

\section{X-ray Diffraction Phase Analysis}

X-ray diffraction phase analysis revealed that all sampled fossil bones are composed mainly of carbonate fluorapatite (Entry \# 96-901-0507; SG $P 63 / m$; unit cell parameters: $a=9.36480 \AA$ and $c=$ $6.88790 \AA$; Fleet and Liu, 2008) ranging from 89.5 (for Vrabchov dol's fossils) to $99.5 \mathrm{wt} \%$ (for NMNHS F-31442). Apart from fluorapatite as a main mineral phase, the Vrabchov dol samples (U.S., $\mathrm{K}_{2} 1586$ and NMNHS FR-16) contain a considerable amount of calcite (CaCO3), approximately $10 \mathrm{wt} \%$ (Figure 12). Trace amounts of quartz were also detected (NMNHS FR-16 and NMNHS F-31442) and in one of the samples (U.S., $\left.\mathrm{K}_{2} 1586\right)$ marcasite $\left(\mathrm{FeS}_{2}\right)$ was registered as well. For samples U.S., $\mathrm{K}_{2} 1586$ and NMNHS F-31442 the diffraction patterns show a very pronounced diffuse background halo, typical for amorphous component. We have no explanation for the nature of the amorphous compoment.

Using data for the Labirinta cave specimens as a guide, the virtually identical phase composition and phase amounts recovered for the Vrabchov dol fossils ( $90 \%$ carbonate fluorapatite and $\sim 10 \%$ calcite) are in strong support of the argument that specimen U.S., $\mathrm{K}_{2} 1586$ originates from the same sedimentary sequence as specimen NMNHS FR-16. Thus, taking into account the histological similarities described above, we deem it most parsimonious to consider that specimen U.S., $\mathrm{K}_{2} 1586$ is not re-deposited from older sediments, nor it originates from another level of the Late Cre-

FIGURE 9 (on previous page). Osteohistology of the Bulgarian hadrosauroid in transmitted cross-polarized and plane-polarized light. Arrow in the lower right corner of each image indicates the direction of the periosteum. 1, Laminar bone tissue in the deep cortex of specimen NMNHS Mos19-1. The primary osteons are mostly of the longitudinal variety, or are short circumferential. The woven component dominates the bone matrix. Secondary osteons are scattered through the cortex; 2, Laminar bone tissue in the mid-cortex of specimen NMNHS Mos19-1. Note the much brighter appearance of the bone scaffolding, which is indicative of significant increase of the parallel-fibered component; 3, Laminar bone tissue in the mid-cortex of specimen NMNHS Mos19-3. The bone matrix is predominantly parallel-fibered in nature, as evidenced by the highly anisotropic optical character of the bone tissue. The degree of histological preservation is high enough to allow observation of the morphology of the osteocyte lacunae at medium magnifications; 4, Laminar bone tissue with large amounts of parallel-fibered tissue in the bone matrix in the deep cortex of specimen NMNHS Mos19-4. Locally, radially oriented primary osteons connect consecutive laminae giving the bone tissue a sub-plexiform appearance. The presence of erosional rooms indicates ongoing process of bone resorption; 5, Laminar bone tissue in the mid-cortex of specimen NMNHS Mos19-6; 6, Numerous large and irregularly shaped osteocyte lacunae in the woven bone scaffolding of the laminar bone in the deep cortex of NMNHS Mos19-6. The canaliculi system and its characteristics are easily observed at higher magnifications. Abbreviations: er-erosional room; pfb-parallel-fibered bone; po-primary osteon; so-secondary osteon. Scale bar equals 1, 4-5-500 $\mu \mathrm{m} ; 2-3-200$ $\mu \mathrm{m} ; 6-50 \mu \mathrm{m}$. 

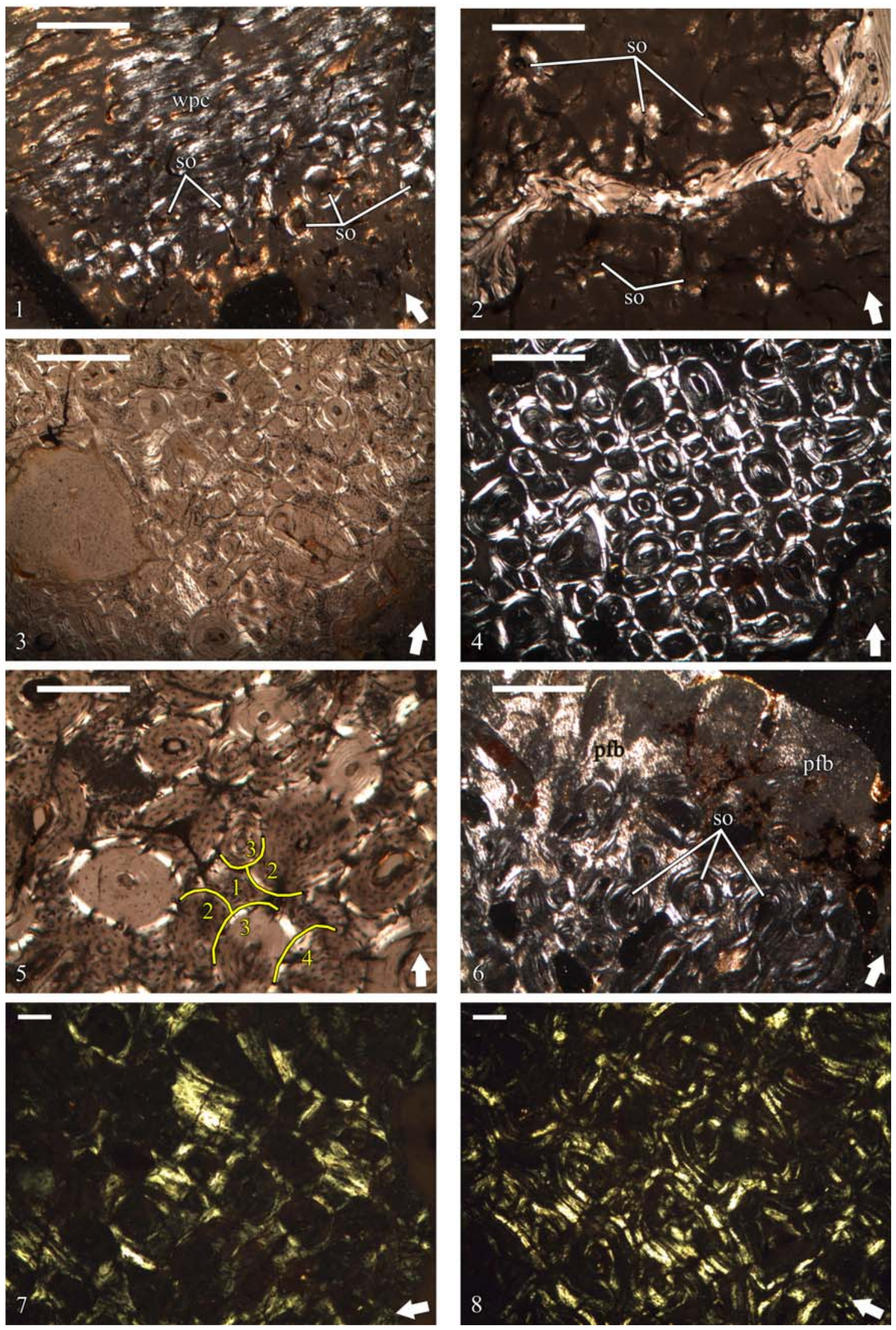

FIGURE 10 (caption on next page). 
taceous rock succession between the villages of Bankya and Vrabcha.

\section{Crystallite Size Estimation}

According to Scherrer's formula average crystallite size is determined as follows (Klug and Alexander, 1974):

$$
L_{h k l}=K \lambda /(\mathrm{FWHM} \cos \theta)
$$

where $L_{h k l}$ is the average crystallite dimension, $K$ is the Scherrer's constant (so-called shape factor, typically $=0.94$ for small cubic crystals of uniform size), $\lambda$ is the wavelength of the radiation used, in $\AA$ (1.5406 $\AA$ for $\left.\mathrm{CuKa}_{1}\right)$, FWHM is the full width at half maximum, and $\theta$ is half the diffraction angle for the reflection measured, in degrees. It should be noted that when using this equation it's very important to choose an appropriate value of shape factor K (depending on the shape of the crystallite), which may vary between 0.62 and 2.08 .

Apatite has a hexagonal crystal structure (SG $P 63 / m$ ) with [001] crystallographic direction aligned along the length of the crystals (Dumont et al., 2011; Frank-Kamenetskaya, 2008). Based on this structure, the average crystallite size (otherwise referred to as coherently diffracting domains) can be determined from the peak broadening of $(00 /)$ and $(h 00)$ reflections.

FWHM of 002 and 300 principal reflections corresponding to the length and width of the apatite crystallites were measured after conducting a profile fitting for accurate determination of the peak parameters, followed by a correction for the instrumental contribution to the peak width. Because both the imperfection of the crystallite (microstrain) and the crystallite size may contribute to peak broadening, considering that strain broadening is negligible, the average crystallite sizes $(\AA)$ were determined from the Scherrer equation (Klug and Alexander, 1974) with the Scherrer's constant K = 1.

FIGURE 10 (figure on previous page). Osteohistology of the Bulgarian hadrosauroid in transmitted cross-polarized light. Arrow in the lower right corner of each image indicates the direction of the periosteum. 1, Locally restricted bone remodeling in the cortex of NMNHS Mos19-1-formation of secondary osteons in reticular primary bone at the transition towards primary bone tissue of laminar type; 2 , Scattered secondary osteons formed over the reticular primary bone tissue of the deep cortex of NMNHS Mos19-2; 3, Haversian bone tissue in the inner cortex of NMNHS Mos19-3; 4, Haversian bone tissue in the cortex of NMNHS Mos19-4; 5, Detail of the dense Haversian bone of NMNHS Mos19-4 with four generation secondary osteons. Some of the osteons differ in appearance and osteocyte lacunae characteristics; 6, Numerous secondary osteons extending up to the sub-periosteal portions of the cortex of NMNHS Mos19-5; 7, Coarse compacted cancellous bone in the deep cortex of NMNHS F-31442; 8, Dense Haversian bone in the outer cortex of NMNHS F-31442. Abbreviations: pfb-parallel-fibered bone; so-secondary osteon; wpc-woven-parallel complex. Scale bar equals 1-4, 6-500 $\mu \mathrm{m} ; 5,7-8-200 \mu \mathrm{m}$.
It is well established that biological apatites are water-containing non-stoichiometric carbonate hydroxyapatites with $\mathrm{Ca}^{2+}$ and/or $\mathrm{OH}^{-}$ion deficiencies (Combes et al., 2016; Frank-Kamenetskaya, 2008) a few tens of nanometers in size. However, mineral composition of hard tissues changes essentially by fossilization processes, which include extensive substitution of $\mathrm{OH}^{-}$ion by $\mathrm{F}^{-}$and increase of crystallinity. Some studies suggest that the latter reflects the taphonomic conditions at burial and the degree of diagenetic alteration (Person et al., 1995, 1996). The process of fluoridisation imposes changes in the apatite structure, expressed by decreasing apatite unit cell a-axis value with the increase of fluoride content. Apart from the shortening along a-axis, it was reported that fluoride incorporation into the carbonate- and xydroxylapatite mineral lattice increases the mineral crystallinity in the direction of the longest $c$ axis of the crystallite, the amount of crystallographic microstrain, the solubility and the optical birefringence (Qiao et al., 2017; Wopenka and Pasteris, 2005; Yan et al., 2013).

Typically for diagenetically altered fossil bones, the main mineral phase constituting all of the sampled specimens is carbonate-fluorapatite. According to the data in the literature apatite crystallite size is larger in fossil bones $(\sim 80 \mathrm{~nm}$ in length), than in subfossil and recent bones $(<15$ nm) (Dal Sasso et al., 2018; Dumont et al., 2011 and references therein; Surmik et al., 2016; Trueman et al., 2008), and crystallite size estimations for the studied material are in line with these observations (Table 2). The length of fluorapatite crystallites varies between specimens from 54 to $87 \mathrm{~nm}$, $31 \mathrm{~nm}$. It is notable that specimens U.S., $\mathrm{K}_{2} 1586$ and NMNHS FR-16 show analogous aspect ratio values (2.0 and 1.9, respectively), with differences in crystallite length between specimens less than $10 \mathrm{~nm}$ at very similar crystallite widths $-31 \mathrm{~nm}$ for U.S., $\mathrm{K}_{2} 1586$ and $28 \mathrm{~nm}$ NMNHS FR-16. Con- 

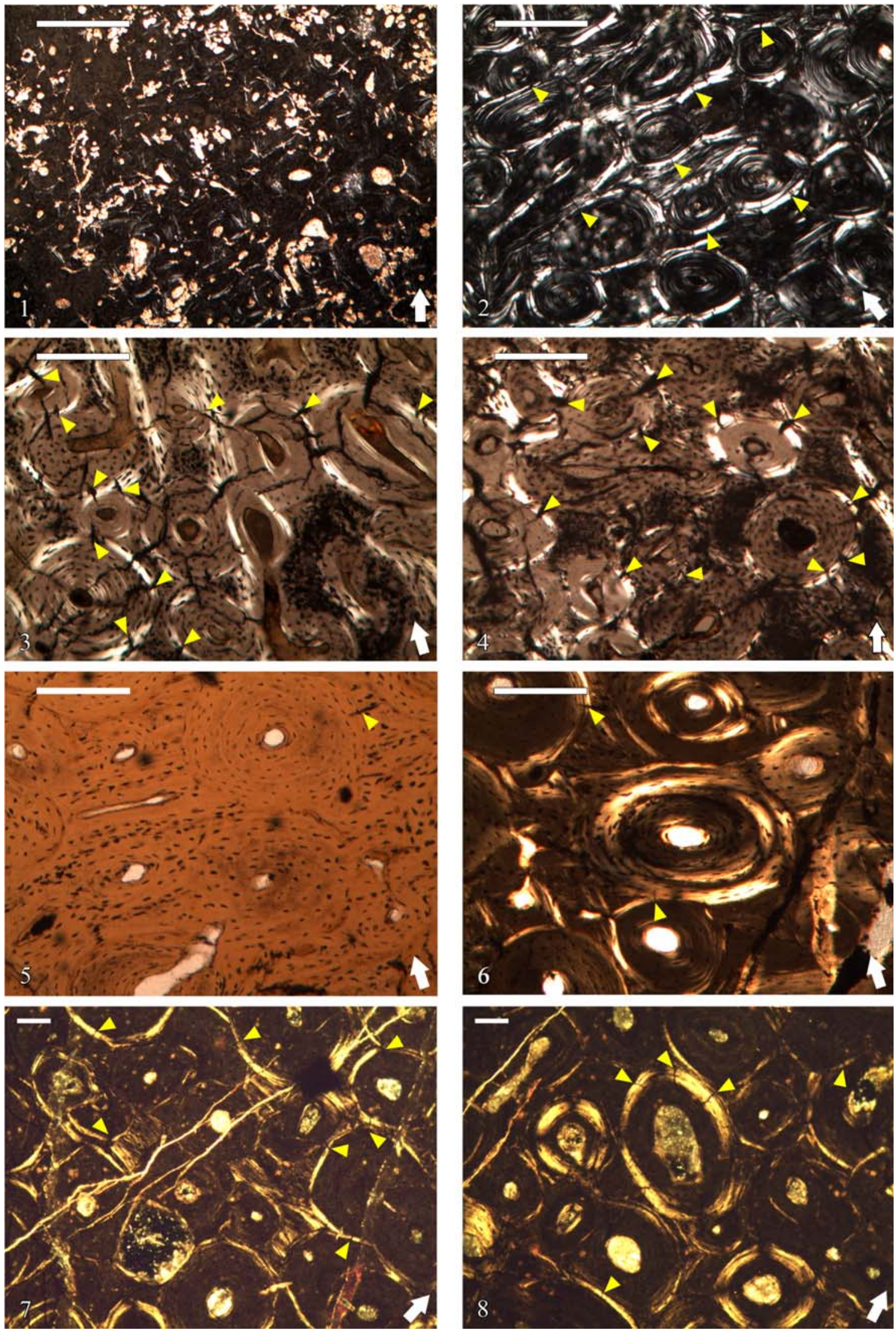

FIGURE 11 (caption on next page). 
versely, specimens NMNHS F-31442 and NMNHS Mos19-2 have a respective crystallite aspect ratio of 2.5 and 3.3 at similar lengths $(69 \mathrm{~nm})$, but a difference in width of approximately 6 nanometers. This variation reflects a difference of crystallite morphology in the two sampled bones. Specimen NMNHS Mos19-3 is characterized by the longest crystallite dimensions, $87 \mathrm{~nm}$, and with a width of $22 \mathrm{~nm}$ it has the highest aspect ratio value of all sampled herein fossils.

The average crystallite size along the $c$ - and a-axis of the samples from Vrabchov dol (specimens U.S., $\mathrm{K}_{2} 1586$ and NMNHS FR-16) and the Labirinta cave (specimens NMNHS F-31442, NMNHS Mos19-2, and NMNHS Mos19-3) reveals a clear difference in the morphology and dimensions of apatite bone crystallites in the fossils from the two localities (Figure 13). While bone crystallites of the Labirinta cave specimens exhibit a large variation in size and morphology, ranging from elongated plate-like to decidedly needle-like, in the Vrabchov dol specimens, despite small size variation, crystallites have virtually identical plate-like morphology. One possible explanation could be variations in the chemical composition (carbonate content for example, or other ion substitutions), which imposes some structural disorder (microstrain), leading to diffraction line broadening (Elorza et al., 1999; Leventouri et al., 2000). Ultimately, observed bone crystallite differences between specimens (and, by extention, between localities) probably reflect their different diagenetic history, and in the case of the Labirinta cave speci- mens, local variations in taphonomic and/or diagenetic conditions. Even if the strong similarity in crystallite morphology between U.S., $\mathrm{K}_{2} 1586$ and NMNHS FR-16 does not indicate taxonomic relatedness, it is further indirect evidence linking the former specimen with the rock sequence sourcing the latter.

\section{Mineralogy of the Vrabchov Dol's Fossils}

Observations reveal that the medullary region of U.S., $\mathrm{K}_{2} 1586$ is filled with large monocrystals of calcite, up to $2-3 \mathrm{~mm}$ in size. Additionally, rhombohedral dolomite and quartz crystals $(0.07-0.12 \mathrm{~mm})$ are also present (Figure 14.1).

The bone trabeculae of the cancellous bone tissues developed perimedullary are composed of recrystallized apatite. Similarly to the medullar zone, inertrabecular spaces are infilled with large calcite monocrystals, which, on some occasions, can encompass adjacent intertrabecular spaces, and with calcite mosaics (Figure 14.2). A later process of dolomitisation has affected the intertrabecular spaces, as evidenced by the presence of rhombohedral dolomite crystals, which vary between 0.04-0.06 $\mathrm{mm}$ in size.

Haversian canals near the medullar region are filled by calcite mosaics, with some marcasite crystals also observed (the marcasite is determined by $\mathrm{X}$-ray analysis, because it is optically indiscernible from pyrite in transmitted light). Compact cortical bone of U.S., $\mathrm{K}_{2} 1586$ is composed of recrystallized apatite. Locally, newly formed apatite type mineral overprints the original histological features of the

FIGURE 11 (figure on prevous page). Comparison of secondary osteon radial microcracks and diagenetic alterations in the bones of Bulgarian non-avian dinosaurs. Arrow-heads point at selected microcracks which best illustrate the abundance of these structures and differences across specimens. Arrow in the lower right corner of each image indicates the direction of the periosteum. 1, Gross appearance of the Haversian bone in the cortex of NMNHS F-31436 (ornithomimosaurian humerus) in cross-polarized light. Bright spots and areas mark diagenetic mineralization, while dark brown/rusty colored areas indicate diagenetic alterations; 2, Detail of the Haversian bone of NMNHS F-31436 in crosspolarized light. Secondary osteons show numerous, but short and, more or less, "closed" radial microcracks; 3, Detail of the Haversian bone of specimen NMNHS Mos19-3 (unidentified cortical fragment) in cross-polarized light. Diagenetic mineralization, in the form of opaque optically isotropic mineral phase, is infilling diagenetic fractures, osteocyte lacunae and the vascular canal of some secondary osteons. Radial microcracks are numerous, well expressed, and sometimes widened; 4, Detail of the Haversian bone of specimen NMNHS Mos19-4 (unidentified cortical fragment) in cross-polarized light. Virtually identical in its characteristics to the Haversian tissue of NMNHS Mos19-3; 5, Secondary osteons in the deep cortex of U.S., $\mathrm{K}_{2} 1586$ (?titanosaurian partial diaphysis) in plane polarized light. Opaque mineral of diagenetic origin infills bone tissue's osteocyte lacunae and some vascular canals. Other diagenetic alterations include fracturing. Osteonal radial microcracks are relatively rare, short, and "closed"; 6, Part of the same cortical area illustrated in 5, but in cross-polarized light, with some larger diagenetic fractures, partially filled with mineral phase, visible on the right side of the image; 7, Detail of the Haversian bone of NMNHS FR-16 (?titanosaurian long bone fragment) in cross-polarized light. Similarly to U.S., $\mathrm{K}_{2} 1586$ the bone wall is affected by diagenetic fracturing and opaque mineral phase is deposited in osteocyte lacunae and vascular canals. Radial microcracks are slightly more frequent, but identically "closed" and short in length; 8, Detail of the Haversian bone of NMNHS FR-16 in cross-polarized light. Scale bar equals 1-500 $\mu \mathrm{m}$; 2-6-200 $\mu \mathrm{m}$; 7-8-100 $\mu \mathrm{m}$. 


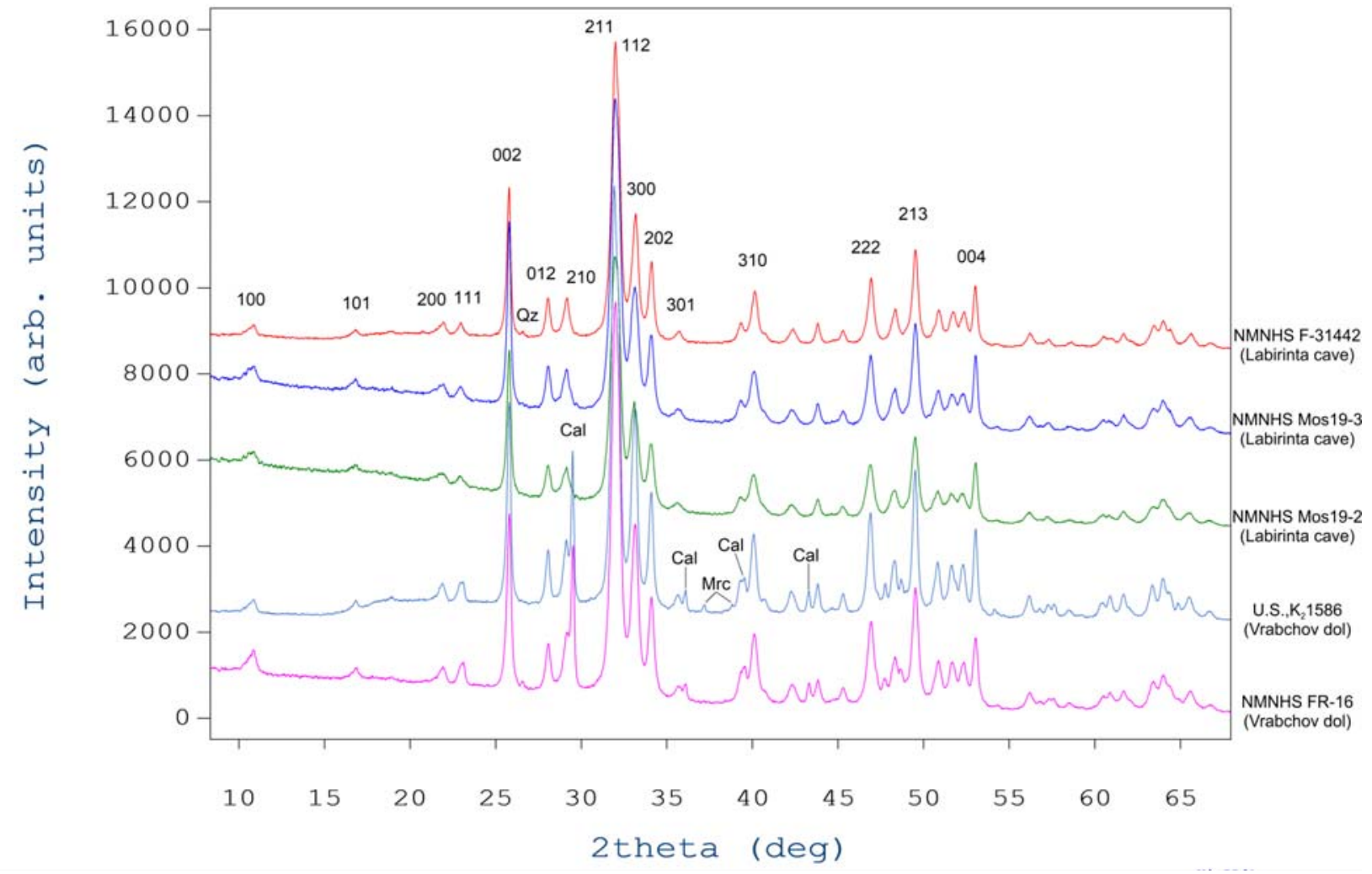

FIGURE 12. X-ray diffraction patterns of fossil bones from Vrabchov dol and Labirinta cave. The Miller indices of different Bragg reflections of fluorapatite are given on the top diffractogram. Abbreviations: Cal-Calcite; Mrc-Marcasite; Qz-Quartz.

cortex (Figure 14.3). Newly formed clear transparent apatite monocrystals infill the lumina of both the primary and the secondary osteons in outer regions of the preserved cortex. Few marcasite crystals are also present. Osteocyte lacunae are filled, in general, by marcasite. Marcasite mineralization is also developed over spatially restricted areas of the cortex where it completely obscures histological details.

The whole compacta is fractured, especially in its outer half, with numerous fine sub-parallel fractures filled in by calcite mosaics (Figure 14.4). In the central parts of some of the fractures a later generation of calcite is developed over the mosaics. Along the fractures, as well as in their vicinity, the apatite exhibits a spotty-striped recrystallization. Smaller fractures, or microfractures, among the osteons are infilled by microcrystalline calcite (micrite).

The extensive nature of cortical fracturing of specimen U.S., $\mathrm{K}_{2} 1586$ when compared to specimen NMNHS FR-16, might indicate that the bone fragment originates from, or in proximity to, that part of the outcrop, which is more affected by tectonic processes.

In terms of the mineral phase composing the bone tissues, the specimen NMNHS FR-16 is identical to U.S., $\mathrm{K}_{2} 1586$-the tissues consist of recrystallized apatite. However, there are some notable differences in the characteristics of the mineral infillings of the medullary region, intertrabecular spaces and lumina.

Calcite mosaics infill the medullar region of the bone, as well as the intertrabecular spaces. Apparently, there are no large calcite monocrystals of the size observed in U.S., $\mathrm{K}_{2} 1586$ (Figure 14.5). Specific for this specimen are the blade calcite syntaxial overgrowths encrusting the bone trabeculae of the cancellous bone (Figure 14.6-7). The trabeculae consist almost entirely of recrystallized apatite. Infilling of the voids by calcite mineralization is as follows: (1) crystallization of calcitic blade-overgrowths along the trabeculae, followed by (2) formation of calcite mosaics, which fill out the remaining space.

The Haversian bone exhibits progressively lower degree of bone apatite recrystallization in 
TABLE 2. Full width at half maximum (FWHM $\left.{ }^{\circ} 2 \theta\right)$ of 002 and 300 fluorapatite reflections; average crystallite size estimation $(\AA)$ along a- and $c$ - crystallographic directions and corresponding aspect ratio (length/width).

\begin{tabular}{lccccc}
\hline \multicolumn{1}{c}{ Sample } & $\mathbf{0 0 2}$ & $\mathbf{3 0 0}$ & $\begin{array}{c}\text { Crystallite size } \\
\text { along } \boldsymbol{c} \text {-axis }\end{array}$ & $\begin{array}{c}\text { Crystallite size } \\
\text { along a-axis }\end{array}$ & $\begin{array}{c}\text { Aspect } \\
\text { ratio } \\
\mathbf{( I / w )}\end{array}$ \\
\hline NMNHS FR-16 & 0.3 & 0.46 & 542 & 276 & 1.9 \\
U.S., K 1586 & 0.28 & 0.42 & 626 & 309 & 2 \\
NMNHS F-31442 & 0.27 & 0.46 & 686 & 274 & 2.5 \\
NMNHS Mos19-2 & 0.26 & 0.56 & 687 & 209 & 3.3 \\
NMNHS Mos19-3 & 0.24 & 0.54 & 871 & 221 & 3.9 \\
\hline
\end{tabular}

periosteal direction. Outermost positioned secondary osteons show recrystallization only of bone lamellae closest to the lumen. Unlike in U.S., $\mathrm{K}_{2} 1586$, calcite mosaics are developed inside lumina. Two systems of fractures, with the later one oriented oblique to the earlier system, are developed in the cortex (Figure 14.8). Earlier fractures are filled by apatite type mineralization. Locally, a superimposed spotty-striped type recrystallization of the apatite is present and associated with fine microfractures oriented transversally to the bone's long axis. Microfractures cutting through the secondary osteons are filled by micrite. These are formed after the apatite recrystallization as evidenced by the cross-cutting relationship with recrystallized areas and/or fractures.

With results from the x-ray diffractometry and comparative histology analyses leaving little doubt in the co-provenance of specimens U.S., $\mathrm{K}_{2} 1586$ and NMNHS FR-16, the observed mineralogical

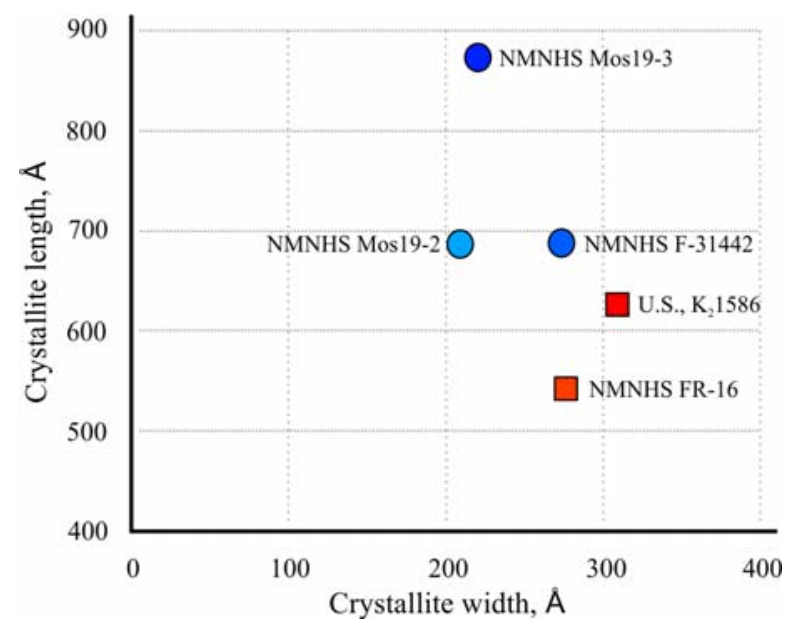

FIGURE 13. Average bone apatite crystallite size (in $\AA$ ) for the fossil bones from Vrabchov dol and Labirinta cave. differences between the two can be explained either with spatial variation in the taphonomic and diagenetic conditions within the fossiliferous layer, or with each specimen originating from different rock layer within the studied sedimentary section.

\section{Diagnostic and Biological Significance of Laminar Bone's Bone Matrix Organization}

The observation of a peculiar type of bone tissue characterized by dense vascularization and spatially moderately to highly organized bone scaffolding in the long bones of several dinosaur taxa, mostly, but not only, titanosaurs (Benton et al., 2010; Stein et al., 2010; Company, 2011; Klein et al., 2009, 2012), has led to revisions of the views on the process of osteogenesis and relevant terminology (Stein and Prondvai, 2014; Prondvai et al., 2014b). Some recent work in progress (Caux et al., 2017), however, casts a doubt on the presence of genuine biological signal in this bone tissue type and suggests that it is just an artifact of the diagenetic alterations undergone by the bone during fossilization. Thus, the presence of highly vascularized bone tissues not conforming to the traditional definition of the fibrolamellar complex in the studied material warrants a critical evaluation of the role of diagenesis in shaping the observed histological characteristics of the fossils from Vrabchov dol.

The fluorapatite nature of the mineral phase constituting the bone tissue of sampled specimens and the larger size of bone crystallites relative to crystallite size of fresh bones (Dal Sasso et al., 2018; Dumount et al., 2011) clearly indicates that the internal structure and composition of studied fossils have undergone diagenetic alteration. Differences in average crystallite size and crystallite morphology between specimens (Figure 13) suggest variation in the degree of recrystallization and changes during diagenesis experienced by the fossils, although differences might be reinforced by in- 

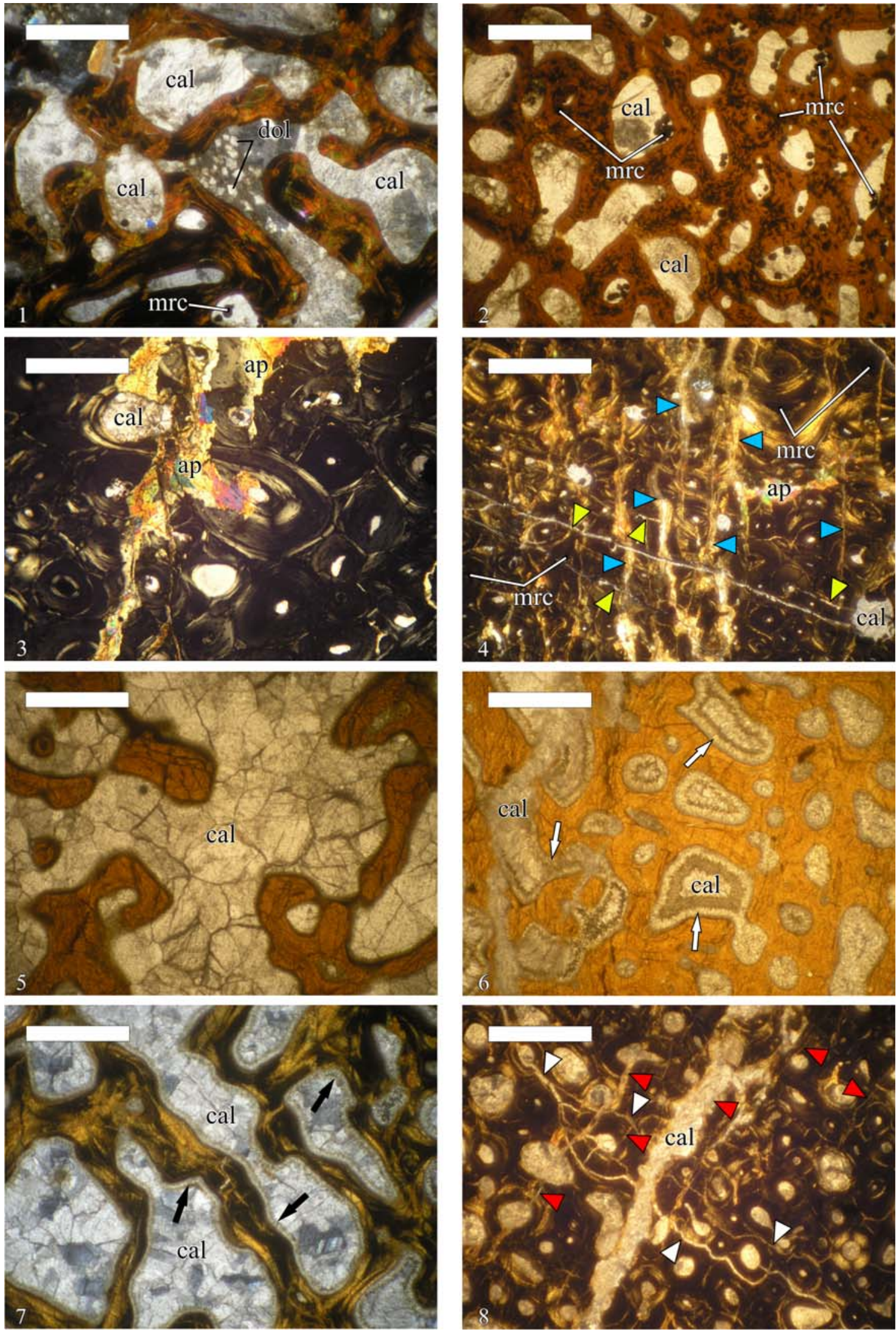

FIGURE 14 (caption on next page). 
vivo characteristics of bone tissues related to intraskeletal, intra- or interspecies variability. It is worth noting that despite the different morphology and size of bone crystallites, the hadrosauroid material shows highly vascularized primary bone tissue with parallel-fibered to lamellar bone scaffolding very similar to the Vrabchov dol's fossils (Figure 9.3-4). Furthermore, the degree of preservation of histological detail in studied specimens is high with even the canaliculi system easily observable (Figure 9.6). Specimen NMNHS FR-16 also has strongly anisotropic primary bone tissue.

Our mineralogical observations back up the $x-$ ray diffractometry data and confirm that, indeed, the bone matrix of the Vrabchov dol specimens has undergone some degree of recrystallization during the process of diagenesis.

The presence of bone tissues with similarly unusual characteristics in fossils with differing degree of crystallinity/recrystallization of bone apatite crystallites, fossilized in different environments and under different conditions, seem to reflect a bone tissue peculiarity, which is not solely the result of a diagenetic alteration of the bone matrix. Additionally, even though it is preserved mostly as patches and interstices, it is observable that the laminar bone of U.S., $\mathrm{K}_{2} 1586$ exhibits changes in both the bone scaffolding spatial organization, with the woven component replaced by parallel-fibered bone periosteally, and the shape and abundance of osteocyte lacunae, which become less numerous, more elongate, and more organized towards the periosteum.

Bone matrix organization and osteocyte lacunae morphology are histological features typically seen a mean of discerning different bone tissue types and are considered to be indicators of their relative speed of deposition. The changes of these features of the primary bone tissue in periosteal direction in specimen U.S., $\mathrm{K}_{2} 1586$ reflect what is expected from a bone laid down progressively later in the ontogeny, thus it seems likely that even though there is some recrystallization of the bone apatite at play the highly organized bone matrix of the laminar bone is genuine, albeit exaggerated to a degree, and has a biological and histological significance.

\section{Long Bone Fragments or Else?}

In order to correctly evaluate and analyze the osteohistology of studied fossil fragments in taxonomic context, it is necessary to identify the nature of the skeletal element they belong to, and then to ascertain whether they are from an aquatic or terrestrial animal. This might prove a difficult task when working with extremely fragmentary remains, as evidenced by the recent study of Lomax et al. (2018). However, careful interpretation of observed histological features and the suggested age of the Vrabchov dol fossils provide some insights.

The gross morphology, cross-sectional shape, and absence of osteological hallmarks on the bone surface of studied fragments all make it unlikely that they are actually partial cranial elements. Furthermore, unlike the misinterpreted ichthyosaur jaw bones (Redelstorff et al., 2014; Lomax et al., 2018), both U.S., $\mathrm{K}_{2} 1586$ and NMNHS FR-16, show thick compact cortex and extreme degree secondary remodeling. Moreover, U.S., $\mathrm{K}_{2} 1586$ is characterized by primary bone with laminar vascularization, a vascular type not typical for mandibular elements. The rareness of laminar bone in jaw elements is supported by, admittedly limited, histological data from other aquatic sauropsids (Caldwell et al., 2003, figure 2, 3; Caldwell, 2007, figure 5) and archosaurs (Prondvai et al., 2014a). Thus, it seems unlikely that the Vrabchov dol fossils represent partial mandibular or other cranial elements.

Even though the appendicular skeletal elements of aquatic taxa adapted to life in shallow water are characterized by thick cortex surrounding a relatively small medullar region filled with cancel-

FIGURE 14 (figure on previous page). Mineralogy of specimens U.S., $\mathrm{K}_{2} 1586$ and NMNHS FR-16, two putative titanosaurian long bone fragments. 1, Large monocrystals of calcite infilling the intertrabecular spaces in the medullar region of U.S., $\mathrm{K}_{2} 1586$. Note that calcite crystals encompass several adjacent intertrabecular spaces. Small dolomite crystals are developed over the calcite; 2, Perimedullary, the intertrabecular spaces of U.S., $K_{2} 1586$ are filled with calcite monocrystals and mosaics. Marcasite mineralization is infilling smaller voids and is locally developed over the calcite; 3, Locally developed later apatite mineralization overprinting the original histological features of specimen U.S., $\mathrm{K}_{2}$ 1586; 4, Two systems of diagenetic fractures (marked with differently colored arrow-heads) in the cortex of U.S., $\mathrm{K}_{2}$ 1586. Voids in the bone tissue (luminae and lacunae) are filled with calcite, or pyrite; 5 , Calcite mosaics in the medullar region of specimen NMNHS FR-16; 6-7, Calcite syntaxial overgrowths (arrows) encrusting the bone trabeculae of NMNHS FR-16 in the perimedullar region at the transition to the compacta and in the medullar region, respectively; 8 , Systems of diagenetic fractures (marked with differently colored arrow-heads) in the cortex of NMNHS FR-16. Abbreviations: ap-apatite; cal-calcite; dol-dolomite; mrc-marcasite. Scale bar equals 1-250 $\mu \mathrm{m} ; 2-8-1000 \mu \mathrm{m}$. 
lous bone (Francillon-Vieillot et al., 1990), it is reasonable to question the possibility that the two fragments belong to the long bones of aquatic sauropsids. The same condition is typical for the bones of terrestrial taxa of large to very large body size, and with (1) the relatively high vascularization of the primary bone tissues, (2) the model of spatial organization of the primary osteons in U.S., $\mathrm{K}_{2} 1586$, as well as (3) the extensive remodeling present in both specimens, it is clear that the overall histology of studied fossils differs markedly from the histological condition typical for the long bones of ichthyosaurs (de Buffrenil and Mazin, 1990; Houssaye, 2013; Houssaye et al., 2014), mosasauroids (Sheldon, 1997; Houssaye et al., 2013), and other aquatic sauropsids (Houssaye, 2013).

The bone microstructure of any given bone is the result of the combined influence of several interrelated factors, all of which leave a variable but irrevocable imprint on the histology of different skeletal elements (Padian, 2013). Despite cortical thickness and degree of Haversian remodeling bearing significant importance, the type of primary bone tissue and its vascularization pattern are most telling about the skeletal nature of specimen U.S., $\mathrm{K}_{2} 1586$. Laminar bone tissue is most frequently present in the long bones of medium-sized to large terrestrial animals (Francillon-Vieillot et al., 1990), and it has been recorded in members of various Mesozoic clades, among which: archosauromorphs (Mukherjee, 2015), pseudosuchians (de Ricqlès et al., 2003, 2008), pterosaurs (de Ricqlès et al., 2000), hadrosaurs (Horner et al., 1999, 2000; Vanderven et al., 2014), non-avian theropods (Varricchio, 1993; de Ricqlès et al., 2003; Horner and Padian, 2004; Bybee et al., 2006), and sauropods (Sander, 2000; Klein and Sander, 2008). A large amount of data indicates that laminar bone tissue is possibly structurally constrained and plays an important mechanical role in the long bones of vertebrate animals, whether it is to lessen the effects of body weight loading experienced by the bone, or to withstand torsional stresses during walking or flying (de Margerie, 2002; Sander and Tückmantel, 2003; de Margerie et al., 2005; Hofmann et al., 2014). Its ubiquitous presence throughout the cortex of specimen U.S., $\mathrm{K}_{2} 1586$ thus indicates that the fossil is most probably a diaphyseal fragment of a large long bone. Other features of the bone appear to support this interpretation. Still due to its incompleteness it cannot be ascertain which skeletal element the fragment belongs to, but cortical thickness makes the possibility of it being a metapodial bone unlikely.
Despite scarce data on the primary bone vascular organization of specimen NMNHS FR-16, its general morphology and histology is consistent with that of terrestrial animal's long bone diaphysis. The overall cross-sectional shape, however, is reminiscent of that of the mid-section of some sauropod dorsal ribs (Waskow and Sander, 2014; but differs markedly from the ribs of other taxa-Woodward and Lehman, 2009). Despite this similarity the fragment does not exhibit any curvature along its long axis as is expected if it indeed represents a partial rib. Although ribs are also commonly subjected to considerable secondary bone remodeling, the extreme nature of the Haversian bone in NMNHS FR-16 might indicate that the specimen is a fragment of a smaller long bone element (Padian et al., 2016). Given existing uncertainties and with all of the histological features of the specimen in mind, we take the latter possibility as most parsimonious and consider NMNHS FR-16 to be a diaphyseal fragment of undetermined long bone.

The only Mesozoic tetrapods with long bones that fit the size of fragments U.S., $\mathrm{K}_{2} 1586$ and NMNHS FR-16, that also commonly show highly vascularized primary tissues and extensive secondary remodeling, are the non-avian dinosaurs.

\section{DISCUSSION}

\section{Osteohistological Comparisons and Taxonomic Affinities of the Vrabchov Dol Material}

Among Dinosauria, only two clades, Thyreophora and Sauropoda, have long bones typically characterized by thick compact cortex and medullar region filled with cancellous bone (Sander, 2000; Stein et al., 2013). However, each of these clades exhibits specific osteohistology, which differs in regards of the degree of vascularization of the primary tissues, the spatial organization of the vascular canals, and the features of the bone scaffolding. These differences allow for osteohistological differentiation between members of the two clades, and thus making it possible to test hypothetical taxonomic affinities of fragmentary fossils to either Thyreophora or Sauropoda.

Thyreophora, the group of so-called armored dinosaurs, comprises of two major clades, namely Stegosauria and Ankylosauria, with both of them being generally understudied osteohistologically in comparison with other dinosaurian groups (Redelstorff and Sander, 2009; Stein et al., 2013). Among stegosaurian taxa, only Stegosaurus (Redelstorff and Sander, 2009; Hayashi et al., 2009) and Kentrosaurus (Redelstorff et al., 2013) have had their 
long bone histology studied in detail. The temporal range of the clade Stegosauria (Maidment, 2010), however, along with the Santonian to early Campanian age of the studied fossils, excludes the possibility of the Bulgarian material to pertain to a stegosaurian taxon.

Long bones of all ankylosaurian taxa that have been studied histologically so far, have a cortex composed of tissues of the woven-parallel complex, which show a consistently high degree of spatial organization of the crystallites in the bone matrix (Stein et al., 2013; Ősi et al., 2014). Primary bone vascularization is low, with vascular canals being small and mostly of longitudinal variety (Stein et al., 2013; Ösi and Prondvai, 2013; Ősi et al., 2014). Throughout the cortex, a large number of LAGs are typically present, as long as conditions allow these histological features to be observedankylosaurs exhibit an extreme degree of cortical remodeling, which hinders all histological features of the primary cortical bone. Secondary remodeling and formation of Haversian bone appear to progress at a slower pace in the long bones of nodosaurids in comparison with ankylosaurids, but all ankylosaurs show initiation of these processes early in ontogeny (Stein et al., 2013). Bones of adult individuals are completely remodeled, and in some of them the Haversian bone consists of at least three generations of secondary osteons (Stein et al., 2013; Ősi and Prondvai, 2013; Ősi et al., 2014).

Despite sharing histological features with thyreophoran dinosaurs, namely the parallelfibered to lamellar bone matrix of primary cortical tissues, the osteohistology of the Vrabchov dol's fossils differs from that of both stegosaurs and ankylosaurs in regards of: (1) the higher vascularization of the primary tissues; (2) the laminar organization of the primary osteons (in U.S., $\mathrm{K}_{2} 1586$ ), a pattern not typical for thyreophorans; (3) the higher number of generations of secondary osteons throughout the cortex; and (4) the absence, or rarity, of growth lines.

Being one of the best studied groups of dinosaurs, it is well known that Sauropoda is characterized by some particularly constant osteohistological traits (Curry Rogers and Erickson, 2005), which were established early in the evolution of the clade and are found in its earliest members (Sander et al., 2004). Virtually all extensively studied sauropod taxa have long bones consisting predominantly of highly vascularized tissues of the woven-parallel complex, with laminar, or, less often, subplexiform to plexiform organization of the vascular canals (Curry, 1999; Sander, 2000; Sander et al., 2006; Klein and Sander, 2008; Klein et al., 2009, 2012; Woodward and Lehman, 2009; Stein et al., 2010; Company, 2011). Periosteal bone laid later in ontogeny can be characterized by a large number of longitudinal primary osteons arranged in circumferential rows (Curry, 1999; Sander et al., 2006; Company, 2011; Klein et al., 2012). With the exception of several titanosaurian taxa, which show a large amount of parallel-fibered and/or lamellar component in the bone scaffolding of the primary bone tissues (Klein et al., 2009, 2012; Stein et al., 2010; Company, 2011), the primary cortical bone of sauropods is made of woven bone matrix that is housing well-developed primary osteons-a tissue type known as fibrolamellar bone (Curry Rogers and Erickson, 2005). LAGs are, in general, rarely observed in the long bones of sauropods and tend to form during the later stages of the individual's development (Curry, 1999; Sander, 2000; Sander et al., 2006; Klein et al., 2009; Company, 2011). A peculiar type of growth marks, called "polish lines", are described by Sander (2000) in sauropod taxa Brachiosaurus, Tornieria, Australodocus, Janenschia, and Dicraeosaurus (Tornieria and Australodocus material is referred by Sander [2000] as Barosaurus-Klein and Sander, 2008, p. 259). Some giant non-titanosaur sauropods exhibit intensive Haversian remodeling in adult individuals (Curry, 1999; Wings et al., 2007), but in most taxa the remodeling is less expressed, even late in ontogeny (Sander, 2000; Sander et al., 2006). Titanosaurs are osteohistologically distinctive from other sauropods in the early onset and a much more intensive character of the process of secondary remodeling (Klein et al., 2009, 2012; Woodward and Lehman, 2009; Company, 2011). This condition is brought to the extreme in titanosaurian genera Magyarosaurus and Rapetosaurus, of which even juveniles have heavily remodeled long bone cortices (Benton et al., 2010; Stein et al., 2010; Curry Rogers et al., 2016).

Even though there are not as many circumferential primary osteons in the primary bone of U.S., $K_{2} 1586$ as generally observed in most sauropod taxa, and the laminar architecture of the vascular system in studied bone fragment consists mostly of circumferential rows of longitudinal osteons, this is not particularly unusual for sauropods, especially in older individuals. Rarity of growth marks, or as is the case with U.S., $\mathrm{K}_{2} 1586$-a single LAG in the outermost cortex, is another histological characteristic common for sauropod long bones. The highly 
organized nature of the bone matrix, the laminar organization of the primary osteons, the extensive remodeling throughout the cortex, and the dense Haversian tissue with at least four generations of secondary osteons, all show that U.S., $\mathrm{K}_{2} 1586$ is histologically the most similar to titanosaurs, especially European taxa Ampelosaurus (Klein et al., 2012), Lirainosaurus (Company, 2011), and Magyarosaurus in particular (Benton et al., 2010; Stein et al., 2010). Although we were not able to collect information on the degree of vascularization and vascular patterns of the primary tissue in specimen NMNHS FR-16 due to the heavy secondary remodeling of the bone, other histological features show that it is osteohistologically very similar to U.S., $\mathrm{K}_{2} 1586$, and conforms the long bone histovariability of titanosaurian sauropods.

Based on the results of our osteohistological analysis and comparisons with published data on the bone histology of various dinosaurian groups, it is clear that the fossil bone fragments from Vrabchov dol belong to a dinosaur, and we deem it most parsimonious to tentatively assign them to the Titanosauria. However, being based only on histological data, this interpretation of the taxonomic affinities of studied fossils is to a large degree provisional and may change once more complete material is available for examination.

\section{Remarks on the Ontogenetic Status of Studied Material}

The direct interpretation of collected histological data using the HOS and the RS methods, suggests that the Vrabchov dol's material pertain to individuals close to attaining skeletal maturity. However, due to method limitations (Klein and Sander, 2008; Mitchell et al., 2017), it is imperative to evaluate any additional ontogenetic indicators present in the specimens in order to access more accurately their ontogenetic status.

In sauropod dinosaurs spatial organization of the primary bone vascular system in circumferential rows of longitudinal osteons generally occurs in individuals considered to be biologically at later ontogenetic stages, close to attainment of skeletal maturity (Curry, 1999; Sander et al., 2006; Company, 2011; Klein et al., 2012). Wide lumina of the subperiosteal primary osteons in U.S., $\mathrm{K}_{2} 1586$, however, indicate that the bone was still experiencing active appositional growth at the time of death. The presence of a LAG subperiosteally is a condition observed in sexually mature sauropods (Curry, 1999; Sander, 2000; Sander et al., 2006; Klein et al., 2009; Company, 2011), and is in accordance with the ontogenetic signal of the vascular architecture. The sum of all osteohistological features of U.S., $\mathrm{K}_{2} 1586$ indicates that the specimen pertains to a sexually mature individual in the later stages of its ontogeny, possibly approaching, but not yet reached, skeletal maturity.

Compared to U.S., $\mathrm{K}_{2} 1586$, NMNHS FR-16 appears to be histologically older, based on the almost complete secondary remodeling of the cortex. The formation of dense Haversian tissue has erased ontogenetically informative features of the primary bone, thus precluding meaningful interpretation of specimen's histology in ontogenetic context. Observable characteristics of preserved primary bone are equivocal-the highly organized bone matrix and apparent avascularity could either indicate bone tissue formed late in ontogeny when the growth has significantly slowed down, or are artifact of the intensive process of bone remodeling. Even without an external fundamental system, or an analogous histological structure marking the attainment of skeletal maturity, straight interpretation of NMNHS FR-16 osteohistology heavily implies that the fossil fragment is part of a bone of a skeletally mature animal. However, in accordance with the results of Padian et al. (2016), we refrain from assigning an adult ontogenetic status to the specimen. Considering all of the collected histological information we prefer a conservative approach and deem NMNHS FR-16 as a fragment pertaining to the skeleton of a not fully grown individual.

Titanosauria is a taxonomically diverse group of derived sauropod dinosaurs, which achieved global distribution during the Cretaceous and proliferated until the very end of the Mesozoic (Curry Rogers, 2005). Considering the large to gigantic body size of most sauropods, especially titanosaurs (Sander et al., 2011), the putative titanosaurian fossil fragments from Vrabchov dol, albeit extremely incomplete, are of interest due to their apparent small size. Small sized long bones in taxa, which belong to groups characterized by a large adult body size, could be explained either by immaturity of the specimen, or small adult size, a problem discussed in relation to the hadrosauroid material from the Labirinta cave (Godefroit and Motchurova-Dekova, 2010). Although several sauropod taxa are known to exhibit small body size (Sander et al., 2011), a dwarf status is confirmed via bone histology data only for the Kimmeridgian basal macronarian Europasaurus (Sander et al., 2006), and the Maastrichtian titanosaur Magyarosaurus (Benton et al., 2010; Stein et al., 2010). If 
our taxonomic and ontogenetic interpretation of the osteohistology of the two studied bone fragments is correct and supported by additional material, then specimens U.S., $\mathrm{K}_{2} 1586$ and NMNHS FR-16 could potentially represent the third documented case of dwarfism in Sauropoda. However, the currently available fossil and histological data cannot test this hypothesis with the necessary degree of rigor and the problem of the small size of Vrabchov dol's fossils remains open.

\section{The Putative Bulgarian Titanosaur and the European Late Cretaceous "Sauropod Hiatus"}

Late Cretaceous sauropod fossil record in Europe is particularly patchy and mostly restricted to the Cenomanian and late Campanian to Maastrichtian (Csiki-Sava et al., 2015), leaving time interval of about 20 million years almost devoid of sauropod remains. This apparent absence of sauropod dinosaurs in mid-Late Cretaceous vertebrate communities of Europe, or "sauropod hiatus", led some authors to hypothesize that the group underwent an extinction event early in the Late Cretaceous and was later re-introduced to European faunas during the late Campanian via immigration from Africa (Le Loeuff, 1993). Still, the possibility that the hiatus is actually an artifact of paleoecological and taphonomic bias was considered a viable alternative explanation for the observed pattern (Le Loeuff, 1993). Later studies have indicated that titanosaurian sauropods, the dominant sauropod clade during the Late Cretaceous, exhibit preferences to inland habitats (Butler and Barrett, 2008; Mannion and Upchurch, 2010). Sedimentary deposits from terrestrial environments with postCenomanian to Campanian age are rare in the European geologic record as a result of the high sea levels and the small area of emergent landmasses (Csiki-Sava et al., 2015; and references there in), thus greatly limiting the potential for preservation of titanosaurian remains. Discoveries of sauropod tracksites from the Santonian of the Apulian platform (Nicosia et al., 1999), and from the late Turonian-early Coniacian of the AdriaticDinaric carbonate platform (Mezga et al., 2006), clearly show that sauropods were present on the European archipelago during the supposed "sauropod hiatus". These findings significantly shorten the temporal range of the hiatus and suggest that the lack of sauropod body fossils is an artifact of sampling bias due to rareness of inland deposits (Mannion and Upchurch, 2011). Recently a single sauropod tooth from the Santonian of Hungary, the first sauropod body fossil from the interval late
Cenomanian-late Campanian, further confirms the presence of this dinosaurian clade in Europe throughout the Late Cretaceous and questions the reality of the hypothesized hiatus (Ösi et al., 2017).

The two Santonian or lower Campanian bone fragments, which we tentatively assign to a titanosaurian sauropod in this study, add to a growing amount of data, which indicates continuous presence of sauropod dinosaurs in the Late Cretaceous of Europe, and lend further support to the hypothesis that the idea of a "sauropod hiatus" is incorrect and simply result of paleoecological and/or sampling bias. Furthermore, pending more precise dating, the Vrabchov dol's material could potentially shrink the still existing gap in the fossil record of European sauropods.

Albeit putative in their taxonomic interpretation, the titanosaurian fossils studied herein clearly show that crucial pieces of information, holding the potential to greatly expand our knowledge and understanding of dinosaur faunas, their paleobiogeography, composition, adaptation to insular environments, and evolution, not only during the Late Cretaceous of Europe, but on a global scale throughout the Mesozoic, are hidden, awaiting discovery in currently paleontologically and geologically understudied regions.

\section{CONCLUSIONS}

We report on two long bone fragments from the Santonian, or early Campanian, sedimentary succession at Vrabchov dol, the first ever tetrapod remains from the Mesozoic of Western Srednogorie, Western Bulgaria. Due to fossils fragmentary nature an osteohistological data was used to establish their taxonomic affinities. The histological analysis reveals an informative combination of bone tissue characteristics, most notably absence of free medullary cavity, thick cortex affected by extreme Haversian remodeling with up to five generations of secondary osteons, absence/rarity of growth marks, and generally highly organized bone matrix, which does allow for tentative assignment of the studied fossils to a titanosaurian sauropod. The interpretation of the new Bulgarian material as belonging to a member of Titanosauria is intriguing, because it comes from a time interval when sauropods are rare in the fossil record of Europe and provides evidence against the hypothesized European "sauropod hiatus". The osteohistologically inferred relatively late ontogenetic stage of the fossil fragments is curious, due to their small size, but the incompleteness of the material precludes further inferences. 
The current paper demonstrates the applicability of paleohistology for the study of the taxonomy of isolated and/or fragmentary dinosaur long bone remains. It also underlines the importance of findings from localities and regions, which are currently poorly researched in terms of dinosaur paleontology, or are yet to yield dinosaur fossils.

For decades Bulgarian paleontologists and geologists have openly dismissed the possibility of non-avian dinosaur remains to be found in the country relying solely on the argument that Mesozoic sediments outcropping on its territory are predominantly marine in origin with the few successions deposited in terrestrial environments apparently devoid of fossils from tetrapod animals. Discoveries made in the last decade (Mateus et al., 2010; Godefroit and Motchurova-Dekova, 2010; this study) not only show that such views need revision, but also hold the potential to greatly expand our knowledge on the European dinosaur communities and provide answers to various important questions about the biology, ecology, and evolution of these impressive animals.

\section{ACKNOWLEDGMENTS}

First and foremost we are sincerely thankful to Mr. A. Tzonkov for bringing the first fossil from Vrabchov dol to us and for allowing us to study it. Without his gesture none of our ongoing research would have been possible. D. Kolarov (GI-BAS) and Dr. S. Velev (Sofia University) prepared some of the studied thin-sections and we acknowledge them for their help. We express our gratitude to Prof. N. Spassov (NMNHS) for granting us access to the fossil material from the Labirinta cave and for allowing us to take samples for histological study, as well as to Prof. I. Kostova, Assoc. Prof. N. Georgiev, Assoc. Prof. V. Mladenova, Dr. D. Yovchev (all from Sofia University) and Prof. K. Stoykova (GI-BAS) for access to microscopes and related equipment necessary to complete our research. Assoc. Prof. O. Mateus (University NOVA of Lisbon) provided comments on the first fossil fragment during the earliest stages of the study, and Dr. J. Mitchell (Institute of Neuroscience and Medicine) took time to discuss the bone histology of titanosaurs with V. Nikolov. Dr. W.T. Blows reviewed early version of this contribution and his comments vastly improved the quality of the text, for which we thank him. We also thank the two anonymous reviewers for their detailed, thoughtful, and fair comments and constructive criticism, which greatly improved our manuscript. We extend our gratitude to Dr. C. Haug for her time and professional editorial work. This research was co-funded by Sofia University, National Museum of Natural History, Sofia, and United Bulgarian Bank (for project "Palaeontological excavations and investigations in search of the Bulgarian dinosaurs"). V. Nikolov would like to dedicate this paper to all those people who said that attempts of studying non-avian dinosaurs in Bulgaria are not worth the efforts.

\section{REFERENCES}

Benton, M.J., Csiki, Z., Grigorescu, D., Redelstorff, R., Sander, P.M., Stein, K., and Weishampel, D.B. 2010. Dinosaurs and the island rule: The dwarfed dinosaurs from the Haţeg Island. Palaeogeography Palaeoclimatology Palaeoecology, 293:438-454. https://doi.org/10.1016/ j.palaeo.2010.01.026

Bonchev, G. 1923. Petrographical studies in West Bulgaria. Annuaire de l'Université de Sofia, Faculté de Biologie, Geologié et Géographie, 19:391-463. (In Bulgarian)

Butler, R. and Barrett, P.M. 2008. Palaeoenvironmental controls on the distribution of Cretaceous herbivorous dinosaurs. Naturwissenschaften, 95:1027-1032. https://doi.org/10.1007/s00114008-0417-5

Bybee, P.J., Lee, A.H., and Lamm, E.-T. 2006. Sizing the Jurassic theropod dinosaur Allosaurus: Assessing growth strategy and evolution of ontogenetic scaling of limbs. Journal of Morphology, 267:347-359. https://doi.org/10.1002/jmor.10406

Caldwell, M.W. 2007. Ontogeny, anatomy and attachment of the dentition in mosasaurs (Mosasauridae: Squamata). Zoological Journal of the Linnean Society, 149:687-700. https:// doi.org/10.1111/j.1096-3642.2007.00280.x

Caldwell, M.W., Budney, L.A., Lamoureux, D.O. 2003. Histology of tooth attachment tissue in the Late Cretaceous mosasaurid Platecarpus. Journal of Vertebrate Paleontology, 23:622-630. https://doi.org/10.1671/0272-4634(2003)023[0622:HOTATI]2.0.CO;2 
Castanet, J., Cubo, J., Montes, L. 2010. Relationship between bone growth rate and bone tissue organization in amniotes: first test of Amprino's rule in phylogenetic context. Animal Biology, 60:25-41. https://doi.org/10.1163/157075610X12610595764093

Caux, H., Stein, K., Snoeck, C., Klein, N., Sander, M.P., and Claeys, P. 2017. Diagenesis as cause for 'modified laminar bone' in sauropod dinosaurs? $8^{\text {th }}$ Bone Diagenesis Meeting: 39.

Chinsamy, A. and Raath, M.A. 1992. Preparation of bone for histological study. Paleontologia Africana, 29:39-44.

Combes, C., Cazalbou, S. and Rey, C. 2016. Apatite biominerals. Minerals, 6:34. https://doi.org/ $10.3390 / \min 6020034$

Company, J. 2011. Bone histology of the titanosaur Lirainosaurus astibiae (Dinosauria: Sauropoda) from the latest Cretaceous of Spain. Naturwissenschaften, 98:67-78. https:// doi.org/10.1007/s00114-010-0742-3

Csiki-Sava, Z., Buffetaut, E., Ösi, A., Pereda-Suberbiola, X., and Brusatte, S.L. 2015. Island life in the Cretaceous-faunal composition, biogeography, evolution, and extinction of land-living vertebrates on the Late Cretaceous European archipelago. ZooKeys, 469:1-161. https:// doi.org/10.3897/zookeys.469.8439

Cubo, J., Ponton, F., Laurin, M., de Margerie, E., and Castanet, J. 2005. Phylogenetic signal in bone microstructure of sauropsids. Systematic Biology, 54:562-574. https://doi.org/10.1080/ 10635150591003461

Curry Rogers, K. 2005. Titanosauria-A phylogenetic overview, p. 50-103. In Curry Rogers, K. and Wilson, J.A. (eds.), The Sauropods: Evolution and Paleobiology. University of California Press, Berkeley and Los Angeles, California.

Curry Rogers, K. and Erickson, G.M. 2005. Sauropod histology: Microscopic views on the lives of giants, p. 303-326. In Curry Rogers, K. and Wilson, J.A. (eds.), The Sauropods: Evolution and Paleobiology. University of California Press, Berkeley and Los Angeles, California.

Curry Rogers, K., Whitney, M., D'Emic, M., and Bagley, B. 2016. Precocity in a tiny titanosaur from the Cretaceous of Madagascar. Science, 352:450-453. https://doi.org/10.1126/ science.aaf1509

Curry, K.A. 1999. Ontogenetic histology of Apatosaurus (Dinosauria: Sauropoda): New insights on growth rates and longevity. Journal of Vertebrate Paleontology, 19:654-665. https:// doi.org/10.1080/02724634.1999.10011179

Dabovski, Ch., Kamenov, B., Sinnyovsky, D., Vasilev, E., Dimitrova, E., and Bayraktarov, I. 2009. Upper Cretaceous geology, p. 303-589. In Zagorchev, I., Dabovski, Ch., and Nikolov, T. (Eds), Geology of Bulgaria. Vol. II. Mesozoic Geology. "Prof. Marin Drinov" Academic Press, Sofia, Bulgaria. (In Bulgarian with English abstract)

Dal Sasso, G., Asscher, Y., Angelini, I., Nodari, L., and Artioli, G. 2018. A universal curve of apatite crystallinity for the assessment of bone integrity and preservation. Scientific Reports, 8:12025. https://doi.org/10.1038/s41598-018-30642-z

de Buffrenil, V. and Mazin, J.-M. 1990. Bone histology of the ichthyosaurs: comparative data and functional interpretation. Paleobiology, 16:435-447. https://doi.org/10.1017/ s0094837300010174

de Margerie, E. 2002. Laminar bone as an adaptation to torsional loads in flapping flight. Journal of Anatomy, 201:521-526. https://doi.org/10.1046/j.1469-7580.2002.00118.x

de Margerie, E., Sanchez, S., Cubo, J., and Castanet, J. 2005. Torsional resistance as a principal component of the structural design of long bones: Comparative multivariate evidence in birds. The Anatomical Record Part A, 282A:49-66. https://doi.org/10.1002/ ar.a.20141

de Ricqlès, A., Castanet, J., and Francillon-Vieillot, H. 2004. The 'message' of bone tissue in paleoherpetology. Italian Journal of Zoology, 71:3-12. https://doi.org/10.1080/ 11250000409356599

de Ricqlès, A., Padian, K., and Horner, J.R. 2003. On the bone histology of some Triassic pseudosuchian archosaurs and related taxa. Annales de Paléontologie, 89:67-101. https:// doi.org/10.1016/S0753-3969(03)00005-3

de Ricqlès, A., Padian, K., Horner, J.R., and Francillon-Viellot, H. 2000. Palaeohistology of the bones of pterosaurs (Reptilia: Archosauria): anatomy, ontogeny, and biomechanical implications. Zoological Journal of the Linnean Society, 129:349-385. https://doi.org/10.1111/ j.1096-3642.2000.tb00016.x 
de Ricqlès, A., Padian, K., Knoll, F., and Horner, J.R. 2008. On the origin of high growth rates in archosaurs and their ancient relatives: Complementary histological studies on Triassic archosauriforms and the problem of a "phylogenetic signal" in bone histology. Annales de Paléontologie, 94:57-76. https://doi.org/10.1016/j.annpal.2008.03.002

Dimitrova, E.N., Ganeva, N.T., Jolkičev, N., Milanova, J.N., and Nachev, I.K. 1981. Upper Cretaceous stratigraphy in Western Srednogorie. Geologica Balcanica, 11:51-66.

Dochev, D. 2006. New biostratigraphic data based on inoceramid bivalves from the interval Upper Turonian-Coniacian in Breznik, West Srednogorie Mountains, Bulgaria. Proceedings of the National Conference with International Participation "Geosciences, 2006":61-64.

Dochev, D. 2009. Inoceramid and Ammonite Fauna and Biostratigraphy of the TuronianSantonian Sediments in Parts of Western Srednogorie. Unpublished PhD thesis, Sofia University "St. Kliment Ohridski”, Sofia, Bulgaria. (In Bulgarian)

Dochev, D. 2015. Turonian (Upper Cretaceous) inoceramid bivalves of the genus Mytiloides from the Sredna Gora Mountains, north-western Bulgaria. Acta Geologica Polonica, 65:101-119. https://doi.org/10.1515/agp-2015-0004

Dochev, D. and Ivanov, M. 2008. New biostratigraphic data based on inoceramid bivalves and ammonites for the Santonian Stage in part of Western Srednogorie. Proceedings 60 Years Geology, Sofia. SU "St. Kliment Ohridski", GGF:24-29. (In Bulgarian)

Dumont, M., Kostka, A., Sander, P.M., Borbely, A., and Kaysser-Pyzalla, A. 2011. Size and size distribution of apatite crystals in sauropod fossil bones. Palaeogeography, Palaeoclimatology, Palaeoecology, 310:108-116. https://doi.org/10.1016/ j.palaeo.2011.06.021

Elorza, J., Astibia, H., Murelaga, X., and Pereda-Suberbiola, X. 1999. Francolite as a diagenetic mineral in dinosaur and other Upper Cretaceous reptile bones (Laño, Iberian Peninsula): microstructural, petrological and geochemical features. Cretaceous Research, 20:169-187. https://doi.org/10.1006/cres.1999.0144

Fleet, M.E. and Liu, X. 2008. Accommodation of the carbonate ion in fluorapatite synthesized at high pressure. American Mineralogist, 93:1460-1469. https://doi.org/10.2138/am.2008.2786

Francillon-Vieillot, H., de Buffrénil, V., Castanet, J., Géraudie, J., Meunier, F.J., Sire, J.Y., Zylberberg, L., and de Ricqlès, A. 1990. Microstructure and mineralization of vertebrate skeletal tissues, p. 471-530. In Carter, J.G. (ed.), Skeletal Biomineralization: Patterns, Processes and Evolutionary Trends, Vol.1. Van Nostrand Reinhold.

Frank-Kamenetskaya, O.V. 2008. Crystal chemistry and synthesis of carbonate apatites-main minerals in living organisms. Proceedings of 9th International Congress for Applied Mineralogy:8-10.

Garilli, V., Klein, N., Buffetaut, E., Sander, P.M., Pollina, F., Galletti, L., Cillari, A., and Guzzetta, D. 2009. First dinosaur bone from Sicily identified by histology and its palaeobiogeographical implications. Nueus Jahrbuch für Geologie und Paläontologie-Abhandlungen, 252:207-216. https://doi.org/10.1127/0077-7749/2009/0252-0207

Godefroit, P. and Motchurova-Dekova, N. 2010. Latest Cretaceous hadrosauriod (Dinosauria: Ornithopoda) remains from Bulgaria. Comptes Rendus Palevol, 9:163-169. https://doi.org/ 10.1016/j.crpv.2010.05.003

Hayashi, S., Carpenter, K., and Suzuki, D. 2009. Different growth patterns between the skeleton and osteoderms of Stegosaurus (Ornithischia: Thyreophora). Journal of Vertebrate Paleontology, 29:123-131. https://doi.org/10.1080/02724634.2009.10010366

Hofmann, R., Stein, K., and Sander, P.M. 2014. Constraints on the lamina density of laminar bone architecture of large-bodied dinosaurs and mammals. Acta Palaeontologica Polonica, 59:287-294. https://doi.org/10.4202/app.2012.0149

Horner, J.R., de Ricqlès, A., and Padian, K. 1999. Variation in dinosaur skeletochronology indicators: Implications for age assessment and physiology. Paleobiology, 25:295-304. https:/ /doi.org/10.1017/s0094837300021308

Horner, J.R., de Ricqlès, A., and Padian, K. 2000. Long bone histology of the hadrosaurid dinosaur Maiasaura peeblesorum: Growth dynamics and physiology based on an ontogenetic series of skeletal elements. Journal of Vertebrate Paleontology, 20:115-129. https://doi.org/10.1671/0272-4634(2000)020[0115:LBHOTH]2.0.CO;2

Horner, J.R. and Padian, K. 2004. Age and growth dynamics of Tyrannosaurus rex. Proceedings of the Royal Society of London. Series B: Biological Sciences, 271:1875-1880. https:// doi.org/10.1098/rspb.2004.2829 
Houssaye, A. 2013. Bone histology of aquatic reptiles: What does it tell us about secondary adaptation to an aquatic life? Biological Journal of the Linnean Society, 108:3-21. https:// doi.org/10.1111/j.1095-8312.2012.02002.x

Houssaye, A., Lindgren, J., Pellegrini, R., Lee, A.H., Germain, D., and Polcyn, M.J. 2013. Microanatomical and histological features in the long bones of mosasaurine mosasaurs (Reptilia, Squamata)-Implications for aquatic adaptation and growth rates. PLoS ONE, 8:e76741. https://doi.org/10.1371/journal.pone.0076741

Houssaye, A., Scheyer, T.M., Kolb, C., Fischer, V., and Sander, P.M. 2014. A new look at ichthyosaur long bone microanatomy and histology: Implications for their adaptation to an aquatic life. PLoS ONE, 9:e95637. https://doi.org/10.1371/journal.pone.0095637

Hurum, J.H., Bergan, M., Muller, R., Nystuen, J.P., and Klein, N. 2006. A Late Triassic dinosaur bone offshore Norway. Norwegian Journal of Geology, 86:117-123.

Ivanov, Ž. 2017. Tectonics of Bulgaria. University Press “St. Kliment Ohridski”, Sofia, Bulgaria. (In Bulgarian)

Jagt, J.W.M., Motchurova-Dekova, N., Ivanov, P., Cappetta, H., and Schulp, A.S. 2006. Latest Cretaceous mosasaurs and lamniform sharks from Labirinta cave, Vratsa district (northwest Bulgaria): a preliminary note. Annales Géologiques de la Péninsule Balkanique, 67:51-63. https://doi.org/10.2298/gabp0667051j

Jolkičev, N.A. 1986. Lithostratigraphic units related to the Upper Cretaceous Series in the West and Central Fore-Balkan. Review of the Bulgarian Geological Society, 47:49-60. (In Bulgarian with English abstract)

Klein, N. and Sander, M. 2008. Ontogenetic stages in the long bone histology of sauropod dinosaurs. Paleobiology, 34:247-263. https://doi.org/10.1666/00948373(2008)034[0247:OSITLB]2.0.CO;2

Klein, N. and Sander, P.M. 2007. Bone histology and growth of the prosauropod dinosaur Plateosaurus engelhardti von Meyer, 1837 from the Norian bonebeds of Trossingen (Germany) and Frick (Switzerland). Special Papers in Palaeontology, 77:169-206.

Klein, N., Sander P.M., Stein, K., Le Loeuff, J., Carballido, J.L., and Buffetaut, E. 2012. Modified laminar bone in Ampelosaurus atacis and other titanosaurs (Sauropoda): Implications for life history and physiology. PLoS ONE, 7:e36907. https://doi.org/10.1371/journal.pone.0036907

Klein, N., Sander, M., and Suteethorn, V. 2009. Bone histology and its implication for the life history and growth of the Early Cretaceous titanosaur Phuwiangosaurus sirindhornae. The Geological Society London, Special Publications, 315:217-228. https://doi.org/10.1144/ SP315.15

Kostadinov, V. 1971a. Tektonische bewegung während des Turon in einem Teil von WestBulgarien. Zeitschrift von Bulgarischen geologischen Gesellschaft, 32:89-94. (In Bulgarian with German abstract)

Kostadinov, V. 1971b. Structure and development of the Pernik fault zone, to the north-west of the Strouma river valley. Bulletin of the Geological Institute, Series Geotectonics, 20:29-56. (In Bulgarian with English abstract)

Kostadinov, V. and Tchounev, D. 1995. Upper Cretaceous. In Zagorchev, I., Kostadinov, V., Tchounev, D., Dimitrova, R., Sapunov, I., Tchoumatchenko, P., and Ynev, S. (eds.), Explanatory Note to the Geological Map of Bulgaria on Scale 1: 100000 Vlasotnice and Breznik sheets. Committee on Geology, Company for Geophysical surveys and Geological mapping, Sofia. (In Bulgarian with English abstract)

Klug, H.P. and Alexander, L.E. 1974. X-Ray Diffraction Procedures for Polycrystallite and Amorphous Materials (second edition). John Wiley and Sons, New York.

Lamm, E.-T. 2007. Paleohistology widens the field view in paleontology. Microscopy and Microanalysis, 13(S02):50-51.

Le Loeuff, J. 1993. European titanosaurids. Revue de Paléobiologie, 7:105-117.

Legendre, L., Le Roy, N., Martinez-Maza, C., Montes, L., Laurin, M., and Cubo, J. 2013. Phylogenetic signal in bone histology of amniotes revisited. Zoologica Scripta, 42:44-53. https://doi.org/10.1111/j.1463-6409.2012.00564.x

Leventouri, T., Chakoumakos, B. C., Moghaddam, H.Y., and Perdikatsis, V. 2000. Powder neutron diffraction studies of a carbonate fluorapatite. Journal of Materials Research, 15:511517. https://doi.org/10.1557/JMR.2000.0076

Lomax, D., De la Salle, P., Massare, J.A., and Gallois, R. 2018. A giant Late Triassic ichthyosaur from the UK and a reinterpretation of the Aust Cliff 'dinosaurian' bones. PLoS ONE, 13:e0194742. https://doi.org/10.1371/journal.pone.0194742 
Maidment, S.C.R. 2010. Stegosauria: a historical review of the body fossil record and phylogenetic relationships. Swiss Journal of Geosciences, 103:199-210. https://doi.org/ 10.1007/s00015-010-0023-3

Mannion, P.D. and Upchurch, P. 2010. A quantitative analysis of environmental associations in sauropod dinosaurs. Paleobiology, 36:253-282. https://doi.org/10.1666/08085.1

Mannion, P.D. and Upchurch, P. 2011. A re-evaluation of the 'mid-Cretaceous sauropod hiatus' and the impact of uneven sampling of the fossil record on patterns of regional dinosaur extinction. Palaeogeography Palaeoclimatology Palaeoecology, 299:529-540. https://doi.org/ 10.1016/j.palaeo.2010.12.003

Marinova, R., Grozdev., V., Ivanova, D., Sinnyovsky, D., Milovanov, P., Petrov, I., and Popov, A. 2010. Explanatory note to the geological map of Bulgaria on scale $1: 50000$ (K-34-45-B) Tsravena Yabuca, K-34-45-G (Vlasotnice), K-34-46-A (Tran-north) and K-34-46-V (Transouth). The Ministry of Environment and Water Develops, Bulgarian National Geological Survey. (In Bulgarian)

Mateus, O., Dyke, G.J., Motchurova-Dekova, N., Kamenov, G.D., and Ivanov, P. 2010. The first record of a dinosaur from Bulgaria. Lethaia, 43:88-94. https://doi.org/10.1111/j.15023931.2009.00174.x

Mezga, A., Meyer, C.A., Tešović, B.C., Bajraktarević, Z., and Gušić, I. 2006. The first record of dinosaurs in the Dalmatian part (Croatia) of the Adriatic-Dinaric carbonate platform (ADCP). Cretaceous Research, 27:735-742. https://doi.org/10.1016/j.cretres.2006.01.001

Minchev, D. 1958. A find of a fossil resin in the Turonian coals at v. Vrabcha, Tran. Annuaire de I'Université de Sofia, Faculté de Biologie, Geologié et Géographie, 51:101-105. (In Bulgarian)

Mitchell, J., Sander P.M., and Koen, S. 2017. Can secondary osteons be used as ontogenetic indicators in sauropods? Extending the histological ontogenetic stages into senescence. Paleobiology, 43:321-342. https://doi.org/10.1017/pab.2016.47

Mukherjee, D. 2015. New insights from bone microanatomy of the Late Triassic Hyperodapedon (Archosauromorpha, Rhynchosauria): Implications for archosauromorph growth strategy. Palaeontology, 58:313-339. https://doi.org/10.1111/pala.12146

Nicosia, U., Marino, M., Mariotti, N., Muraro, C., Panigutti, S., Petti, F.M., and Sacchi, E. 1999. The Late Cretaceous dinosaur tracksite near Altamura (Bari, Southern Italia) I-Geological framework. Geologica Romana, 35:231-236.

Nikolov, I. and Westphal, F. 1976. Mosasaurier-Funde aus der Oberkreide von NordwestBulgarien. Neues Jahrbuch für Geologie und Paläontologie, Monatshefte, 10:608-613.

Nikolov, V. 2015. Osteohistology of the hadrosauroid (Dinosauria: Ornithopoda) from Labirinta cave, Bulgaria: An example of insular dwarfism or simply young giant? $3^{\text {rd }}$ International Symposium on Paleohistology, Program and Abstracts:97.

Ösi, A. and Prondvai, E. 2013. Sympatry of two ankylosaurs (Hungarosaurus and cf. Struthiosaurus) in the Santonian of Hungary. Cretaceous Research, 44:58-63. https://doi.org/ 10.1016/j.cretres.2013.03.006

Ösi, A., Codrea, V., Prondvai, E., and Csiki-Sava, Z. 2014. New ankylosaurian material from the Upper Cretaceous of Transylvania. Annales de Paléontologie, 100:257-271. https://doi.org/ 10.1016/j.annpal.2014.02.001

Ösi, A., Csiki-Sava, Z., and Prondvai, E. 2017. A sauropod tooth from the Santonian of Hungary and the European Late Cretaceous 'sauropod hiatus'. Scientific Reports, 7:3261. https:// doi.org/10.1038/s41598-017-03602-2

Padian, K. 2013. Why study the bone microstructure of fossil tetrapods? p. 1-11. In Padian, K. and Lamm, E.-T. (eds.), Bone Histology of Fossil Tetrapods. Advancing methods, Analysis, and Interpretation. University of California Press, Berkeley and Los Angeles, California.

Padian, K., de Ricqlès, A.J., and Horner, J.R. 1995. Bone histology determines identification of a new fossil taxon of pterosaur (Reptilia: Archosauria). Comptes rendus de l'Académie des Sciences. Série 2. Sciences de la Terre et des Planètes, 320:77-84.

Padian, K., Werning, S., and Horner, J.R. 2016. A hypothesis on differential secondary bone formation in dinosaurs. Comptes Rendus Palevol, 15:40-48. https://doi.org/10.1016/ j.crpv.2015.03.002

Person, A., Bocherens, H., Mariotti, A., and Renard, M. 1996. Diagenetic evolution and experimental heating of bone phosphate. Palaeogeography, Palaeoclimatology, Palaeoecology, 126:135-149. https://doi.org/10.1016/S0031-0182(97)88906-7 
Person, A., Bocherens, H., Saliège, J.-F., Paris, F., Zeitoun, V., and Gérard, M. 1995. Early diagenetic evolution of bone phosphate: An x-ray diffractometry analysis. Journal of Archaeological Science, 22:211-221. https://doi.org/10.1006/jasc.1995.0023

Pfretzschner, H.-U. 2000. Microcracks and fossilization of Haversian bone. Neues Jahrbuch fur Geologie und Paläontologie-Abhandlungen, 216:413-432.

Pfretzschner, H.-U. 2004. Fossilization of Haversian bone in aquatic environments. Comptes Rendus Palevol, 3:605-616. https://doi.org/10.1016/j.crpv.2004.07.006

Prondvai, E., Bodor, E.R., and Ösi, A. 2014a. Does morphology reflect osteohistology-based ontogeny? A case study of Late Cretaceous pterosaurs jaw symphyses from Hungary reveals hidden taxonomic diversity. Paleobiology, 40:288-321. https://doi.org/10.5061/ dryad.k7686

Prondvai, E., Stein, K.H.W., de Ricqlès, A., and Cubo, J. 2014b. Development-based revision of bone tissue classification: the importance of semantics for science. Biological Journal of the Linnean Society, 112:799-816. https://doi.org/10.1111/bij.12323

Qiao, W., Liu, Q., Li, Z., Zhang, H. and Chen, Z. 2017. Changes in physicochemical and biological properties of porcine bone derived hydroxyapatite induced by the incorporation of fluoride. Science and Technology of Advanced Materials, 18:110-121. https://doi.org/ 10.1080/14686996.2016.1263140

Redelstorff, R. and Sander, P.M. 2009. Long bone and girdle bone histology of Stegosaurus: Implications for growth and life history. Journal of Vertebrate Paleontology, 29:1087-1099. https://doi.org/10.1671/039.029.0420

Redelstorff, R., Hübner, T.R., Chinsamy, A., and Sander, P.M. 2013. Bone histology of the stegosaur Kentrosaurus aethiopicus (Ornithischia: Thyreophora) from the Upper Jurassic of Tanzania. The Anatomical Record, 296:933-952. https://doi.org/10.1002/ar.22701

Redelstorff, R., Sander, P.M., and Galton, P.M. 2014. Unique bone histology in partial large bone shafts from Aust Cliff (England, Upper Triassic): an early independent experiment in gigantism. Acta Palaeontologica Polonica, 59:607-615. https://doi.org/10.4202/ app.2012.0073

Sander, P.M. 2000. Longbone histology of the Tendaguru sauropods: Implications for growth and biology. Paleobiology, 26:466-488. https://doi.org/10.1666/00948373(2000)026<0466:lhotts>2.0.co;2

Sander, P.M. and Tückmantel, C. 2003. Bone lamina thickness, bone apposition rate, and age estimates in sauropod humeri and femora. Paläontologische Zeitschrift, 77:161-172. https:// doi.org/10.1007/BF03004566

Sander, P.M., Christian, A., Clauss, M., Fechner, R., Gee, C.T., Griebeler, E.-M., Gunga, H.-S., Hummel, J., Mallison, H., Perry, S.F., Preuschoft, H., Rauhut, O.W.M., Remes, K., Tütken, T., Wings, O., and Witzel, U. 2011. Biology of the sauropod dinosaurs: the evolution of gigantism. Biological Reviews, 86:117-155. https://doi.org/10.1111/j.1469185X.2010.00137.x

Sander, P.M., Klein, N., Buffetaut, E., Cuny, G., Suteethorn, V., and Le Loeuff, J. 2004. Adaptive radiation in sauropod dinosaurs: Bone histology indicates rapid evolution of giant body size through acceleration. Organisms Diversity and Evolution, 4:165-173. https://doi.org/10.1016/ j.ode.2003.12.002

Sander, P.M., Mateus, O., Laven, T., and Knötschke, N. 2006. Bone histology indicates insular dwarfism in a new Late Jurassic sauropod dinosaur. Nature, 441:739-741. https://doi.org/ 10.1038/nature04633

Sheldon, A. 1997. Ecological implications of mosasaur bone microstructure, p. 333-354. In Callaway, J. M. and Nicholls, E.L. (eds.), Ancient Marine Reptiles. Academic Press, San Diego.

Sinnyovsky, D., Marinova, R., and Jelev, V. 2012. Upper Cretaceous lithostratigraphy in the West Srednogorie. Part 1. Review of the Bulgarian Geological Society, 73:105-122.

Sinnyovsky, D., Marinova, R., and Jelev, V. 2013. Upper Cretaceous lithostratigraphy in the West Srednogorie. Part 2. Review of the Bulgarian Geological Society, 74:65-79.

Stein, K. and Prondvai, E. 2014. Rethinking the nature of fibrolamellar bone: an integrative biological revision of sauropod plexiform bone formation. Biological Reviews, 89:24-47. https://doi.org/10.1111/brv.12041

Stein, K. and Sander, M. 2009. Histological core drilling: a less destructive method for studying bone histology. Methods of Fossil Preparation: Proceedings of the First Annual Fossil Preparation and Collections Symposium:69-80. 
Stein, K., Csiki, Z., Curry-Rogers, K., Weishampel, D.B., Redelstorff, R., Carballido, J.L., and Sander, P.M. 2010. Small body size and extreme cortical bone remodeling indicate phyletic drawfism in Magyarosaurus dacus (Sauropoda: Titanosauria). Proceedings of the National Academy of Sciences, 107:9258-9263. https://doi.org/10.1073/pnas.1000781107

Stein, M., Hayashi, S., and Sander, P.M. 2013. Long bone histology and growth patterns in ankylosaurs: Implications for life history and evolution. PLOS ONE, 8:e68590 https://doi.org/ 10.1371/journal.pone.0068590

Surmik, D., Boczarowski, A., Balin, K., Dulski, M., Szade, J., Kremer, B., and Pawlicki, R. 2016. Spectroscopic studies on organic matter from Triassic reptile bones, Upper Silesia, Poland. PLoS ONE, 11:e0151143. https://doi.org/10.1371/journal.pone.0151143

Trueman, C.N., Palmer, M.R., Field, J., Privat, K., Ludgate, N., Chavagnac, V., Eberth, A., Cifelli, R., and Rogers, R. R. 2008. Comparing rates of recrystallization and the potential for preservation of biomolecules from distribution of trace elements in fossil bones. Comptes Rendus Palevol, 7:145-158. https://doi.org/10.1016/j.crpv.2008.02.006

Tzankov, V. 1939. Note sur la présence des reptiles fossils du crétacé supérieur de la Bulgarie du nord. Geologica Balkanica, 3:55-62.

Tzankov, V., Stefanov, J., Dimitrova, N., Vrăbliansky, B., and Enčeva, M. 1960. Géologie de Bourel et des regions avoisinantes entre Trăn et Slivnitsa.-Travaux sur Geologie de Bulagrie, Serie Stratigraphie et teconique, 1:103-131 (In Bulgarian with French abstract)

Tzankov. V. 1968. Upper Cretaceous, p. 253-293. In Tzankov, V. and Spasov, Ch. (eds.), Stratigraphy of Bulgaria. Science and Art, Sofia, Bulgaria. (In Bulgarian)

Vanderven, E., Burns, M.E., and Currie, P.J. 2014. Histologic growth dynamic study of Edmontosaurus regalis (Dinosauria: Hadrosauridae) from a bonebed assemblage of the Upper Cretaceous Horseshoe Canyon Formation, Edmonton, Alberta, Canada. Canadian Journal of Earth Sciences, 51:1023-1033. https://doi.org/10.1139/cjes-2014-0064

Varricchio, D.J. 1993. Bone microstructure of the Upper Cretaceous theropod dinosaur Troodon formosus. Journal of Vertebrate Paleontology, 13:99-104. https://doi.org/10.1080/ 02724634.1993.10011490

Walaszczyk, I. and Cobban, W.A. 2006. Palaeontology and biostratigraphy of the Middle-Upper Coniacian and Santonian inoceramids of the US Western Interior. Acta Geologica Polonica, 56:241-348.

Waskow, K. and Sander, P.M. 2014. Growth record and histological variation in the dorsal ribs of Camarasaurus sp. (Sauropoda). Journal of Vertebrate Paleontology, 34:852-869. https:// doi.org/10.1080/02724634.2014.840645

Werning, S. 2012. The ontogenetic osteohistology of Tenontosaurus tilletti. PLoS ONE, 7:e33539. https://doi.org/10.1371/journal.pone.0033539

Wilson, J.W. 1994. Histology techniques, p. 205-234. In Leiggi, P. and May P. (eds.), Vertebrate Paleontological Techniques. Cambridge University Press, Cambridge, UK.

Wilson, L.E. and Chin, K. 2014. Comparative osteohistology of Hesperornis with reference to pygoscelid penguins: the effects of climate and behaviour on avian bone microstructure. Royal Society Open Science, 1:140245. https://doi.org/10.1098/rsos.140245

Wings, O., Sander, P.M., Tütken, T., Fowler, D.W., and Sun, G. 2007. Growth and life history of Asia's largest dinosaur. Journal of Vertebrate Paleontology, 27:167A.

Woodward, H.N. and Lehman, T.M. 2009. Bone histology and microanatomy of Alamosaurus sanjuanensis (Sauropoda: Titanosauria) from the Maastrichtian of Big Bend National Park, Texas. Journal of Vertebrate Paleontology, 29:807-821. https://doi.org/10.1671/039.029.0310

Wopenka, B. and Pasteris, J.D. 2005. A mineralogical perspective on the apatite in bone. Materials Science and Engineering: C, 25:131-143. https://doi.org/10.1016/ j.msec.2005.01.008

Yan, G., Morible, K., Otsuka, M., Papangkorn, K., and Higuchi, W.I. 2013. Quantitative determination of lattice fluoride effects on the solubility and crystallinity of carbonated apatites with incorporated fluoride. Caries Research, 47:193-202. https://doi.org/10.1159/ 000345080

Zafirov, S. 1950. Géologie de la region de l'Erma entre Tran et la plaine de Pirot. Review of Bulgarian Geological Society, 20:139-182. (In Bulgarian with French abstract)

Zlatarski, G.N. 1927. La géologie de la Bulgarie. University Library, Sofia. (In Bulgarian with French abstract) 